\title{
Fault Growth and Interactions in a Multiphase Rift Fault Network: Horda Platform, Norwegian North Sea
}

\author{
Oliver B. Duffy ${ }^{*}$, Rebecca E. Bell ${ }^{1}$, Christopher A-L. Jackson', Rob L. Gawthorpe ${ }^{2}$, Paul S. \\ Whipp $^{3}$ \\ ${ }^{1}$ Basins Research Group (BRG), Department of Earth Science \& Engineering, Imperial College, Prince \\ Consort Road, London, United Kingdom, SW7 2BP \\ ${ }^{2}$ Department of Earth Science, University of Bergen, P.O. Box 7803, N-5020 Bergen, Norway \\ ${ }^{3}$ Statoil ASA, Sandslivegen 90, 5254 Sandsli, Norway \\ *Present Address of Corresponding Author: Bureau of Economic Geology, Jackson School of \\ Geosciences, The University of Texas at Austin, University Station, Box X, Austin, Texas, 78713-8924, \\ USA (e-mail: oliver.duffy@beg.utexas.edu)
}

Running Title: Fault Growth Characteristics in Multiphase Rifts

Keywords: normal faulting, multiphase rifting, fault growth, fault interactions, fault throw, fault networks, North Sea

Word Count: $\boldsymbol{c a} . \mathbf{8 5 0 0}$ (without abstract and acknowledgements)

\begin{abstract}
:
Physical models predict that multiphase rifts that experience a change in extension direction between stretching phases will typically develop non-colinear normal fault sets. Furthermore, multiphase rifts will display a greater frequency and range of styles of fault interactions than single-phase rifts. Although these physical models have yielded useful information on the evolution of fault networks in map view, the true 3D geometry of the faults and associated interactions are poorly understood. Here, we use an integrated 3D seismic reflection and borehole dataset to examine a range of fault interactions that occur in a natural multiphase fault network in the northern Horda Platform, northern North Sea. In particular we aim to: i) determine the range of styles of fault interaction that occur between non-colinear faults; ii) examine the typical geometries and throw patterns associated with each of these different styles; and iii) highlight the differences between single-phase and multiphase rift fault networks. Our study focuses on a $c a .350 \mathrm{~km}^{2}$ region around the $>60 \mathrm{~km}$ long, N-S-striking
\end{abstract}


Tusse Fault, a normal fault system that was active in the Permian-Triassic and again in the Late Jurassic-to-Early Cretaceous. The Tusse Fault is one of a series of large (>1500 m throw) N-S-striking faults forming part of the northern Horda Platform fault network, which includes numerous smaller (2-10 km long), lower throw ( $<100 \mathrm{~m})$, predominantly NW-SE-striking faults that were only active during the Late Jurassic to Early Cretaceous. We examine how the 2nd-stage NW-SE-striking faults grew, interacted and linked with the N-S-striking Tusse Fault, documenting a range of interaction styles including mechanical and kinematic isolation, abutment, retardation and reactivated relays. Our results demonstrate that: i) isolated, non-interacting and abutting interactions are the most common fault interaction styles in the northern Horda Platform;

ii) pre-existing faults can act as sites of nucleation for 2 nd-stage faults or may form mechanical barriers to propagation; iii) the throw distribution on reactivated 1st-stage faults will be modified in a predictable manner if they are intersected or influenced by 2 nd-stage faults; iv) sites of fault linkage and relay-breaching associated with the first phase of extension can act as preferential nucleation sites for 2nd-stage faults; and v) the development of fault intersections is a dynamic process, involving the gradual transition from one style to another.

\section{Introduction}

Faults that develop during a single phase of extension typically strike sub-perpendicular to the extension direction and show an en échelon or colinear configuration (e.g. Gawthorpe and Leeder, 2000) (Fig 1). Faults with strikes that are oblique to the main rift trend (herein termed 'non-colinear faults') can also develop during a single rift phase, commonly due to breaching of relay zones (e.g. Trudgill et al., 2002), flexure and gravity-driven sliding of the cover above weak layers (e.g. overpressured mudstone or and salt; e.g. Stewart and Clark, 1999) and the development of 'release' faults (e.g. Destro, 1995). Furthermore, non-colinear faults also develop in response to: i) perturbations in the local stress field around pre-existing or broadly synchronous normal faults 
57 (Maerten et al., 1999; 2002); ii) compaction and dewatering, which in some cases leads to radiallyisotropic strain expressed as 'polygonal' faulting (e.g. Cartwright and Lonergan, 1996; Cartwright and Dewhirst, 1998); and iii) the anisotropic effects of pre-existing fabrics that are oriented obliquely to the extension direction (e.g. Morley et al., 2004) (Fig. 1; see also Reeve et al., 2015 for a synthesis). However, the development of non-colinear faults in many of these cases is not pervasive across the fault network and the range of styles of interaction and overall influence of fault interactions in the evolution of the fault network is relatively low (Fig. 1).

In contrast, in multiphase rifts, and particularly where the extension direction during each rift phase differs, faults formed in the first rift phase influence how strain is accommodated in the upper crust in the second rift phase (e.g. Keep and McClay, 1997; Bellahsen and Daniel, 2005; Henza et al., 2011; Whipp et al., 2014). In this situation the later rift phase is characterised by reactivation of pre-

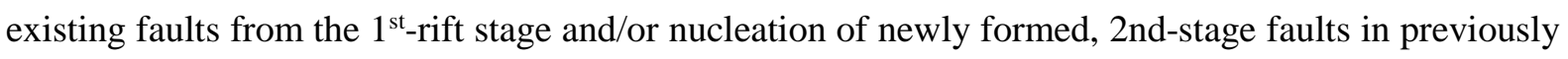
unruptured crust, which generally strike sub-perpendicular to the new extension direction (e.g. Bailey et al., 2005; Henza et al., 2010; 2011; Whipp et al., 2014). Fault networks in multiphase rifts are therefore prone to comprise of pervasive non-colinear fault sets, with interaction and intersections between the non-colinear faults common, as is observed in the Jeanne D'Arc rift (e.g. Sinclair and Withjack, 2008), Gulf of Aden (Bellahsen et al., 2006), Gulf of Thailand (e.g. Morley et al., 2004, 2007), Alaska (Nixon et al., 2014) and the North Sea (Badley et al., 1998; Færseth, 1996; Odinsen et al., 2000; Whipp et al., 2014).

Much of our understanding of how non-colinear faults and fault interactions evolve in multiphase rifts is based on predictions from physical models (e.g. McClay and White, 1995; Bellahsen and Daniel, 2005; Henza et al., 2010; 2011; Chattopadhyay and Chakra, 2013). While these physical models provide important information on the plan-view evolution of faults and fault interactions, the true 3D geometry of the faults and interaction styles remain unknown. Furthermore, there is a general lack of observations of different fault interaction styles from outcrop or subsurface natural examples, although Nelson (2006) and Nixon et al. (2014) provide notable exceptions.

In this study we examine a fault network in a natural multiphase rift to: i) identify a range of styles of fault interaction and/or linkage between $1^{\text {st }}$ and 2 nd-stage faults; ii) examine the tipline 
geometries, branchline characteristics and throw patterns associated with each interaction style; and iii) develop an understanding of how fault interaction styles evolve. To achieve this we integrate observations from a 3D seismic reflection and borehole dataset that covers the northern Horda Platform array, Horda Platform, northern North Sea. This setting is ideal for this study because previous studies demonstrate the area was subject to two rift events, which resulted in the formation of fault sets with different dominant strikes (Badley et al., 1998; Færseth, 1996; Odinsen et al., 2000; Whipp et al., 2014). Furthermore, the relatively shallow burial of the area means faults and branchlines are well-imaged, and an abundance of borehole data allows us to constrain the age of growth strata adjacent to the faults, and hence constrain the temporal evolution of the fault array. Using this information, we improve our understanding of how pre-existing faults influence the development of subsequent fault networks and present a template of fault interaction styles that will aid structural mapping in seismic datasets lacking such clear imaging of faults and their geometric relationships.

\section{Geological Framework}

\subsection{Regional Tectonic Evolution}

The crystalline basement of the northern North Sea was influenced by contractional episodes in the Caledonian (460-400 Ma) and Variscan (400-300 Ma) orogenies (e.g. Ziegler, 1975). During the Devonian, post-orogenic crustal relaxation resulted in the development of major extensional shear zones and intermontane basins, such as those preserved onshore western Norway (e.g. Fossen, 1992; Vetti and Fossen, 2012). These extensional shear zones formed a crustal fabric which is interpreted to have influenced the development of the North Sea basin by modifying the geometry of Mesozoic rift systems and influencing the distribution of thermally-driven Cenozoic subsidence (e.g. Glennie et al, 1987; Ziegler, 1990; Stewart et al., 1992; Bartholomew et al., 1993; Smethurst, 2000).

The first main rift phase (herein termed 'Rift Phase 1') initiated in the Late Permian and continued for 25-37 Myr before ceasing in the Early Triassic (e.g. Ziegler, 1982; Ziegler, 1990; 1992; 

Permian-Triassic fault systems, an E-W extension direction is inferred for Rift Phase 1 (Færseth, 1996; Færseth et al., 1997) (Fig. 2). Faults developed during Rift Phase 1 dip predominantly westward and bound easterly-tilted half-grabens (e.g. Færseth, 1996; Bell et al., 2014) (Fig. 2). a second rift phase (herein termed 'Rift Phase 2') initiated in the Middle Jurassic (e.g. Badley et al., 1988; Underhill and Partington, 1993; Roberts et al., 1995; Coward et al., 2003; Cowie et al., 2005) (Fig. 3). Rift Phase 2 continued until the Early Cretaceous, although the onset and cessation of active faulting across the rift was diachronous (e.g. Coward et al., 2003; Cowie et al., 2005; Bell et al., 2014). Currently, no consensus exists on the direction of extension during Rift Phase 2 in the northern North Sea; some studies invoke a continuation of the E-W extension experienced in Rift Phase 1 (e.g. Stewart et al., 1992; Bartholomew et al., 1993; Brun and Tron, 1993) whereas others propose a rotation of the extension direction to either NW-SE, WNW-ESE or NNE-SSW (e.g. Ziegler, 1990, 1992; Færseth, 1996; Dore et al., 1997; Færseth et al., 1997; Davies et al., 2001). Once Rift Phase 2 ceased, the northern North Sea experienced post-rift thermal subsidence, which was focused in the axis of the Viking Graben (Odinsen et al., 2000).

The magnitudes of extension experienced in Rift Phases 1 and 2 were broadly similar (stretching factors of 1.4-1.5; Roberts et al., 1993; Færseth, 1996; Odinsen et al., 2000), although the way in which extension was distributed varied between phases. Some authors think that, during Rift Phase 1, extension was distributed evenly across the rift (Odinsen et al., 2000) whereas other postulate that extension was greatest in the region that is the present-day Horda Platform (Færseth, 1996; Ter Voorde et al., 2000). In contrast, during Rift Phase 2, extension in the northern North Sea was focused in the Viking Graben (Odinsen et al., 2000; Cowie et al., 2005).

\subsection{Geological Setting of the Horda Platform}

The Horda Platform is a $c a .300 \mathrm{~km}$ long, N-S-trending structural high located along the eastern margin of the Norwegian North Sea, bounded to the west by the North Viking Graben and to the east 
by the Øygarden Fault Complex (e.g. Færseth, 1996; Bell et al., 2014; Whipp et al., 2014) (Fig. 2). The northern part of the platform is dissected by a fault network that comprises a N-S-striking fault set active during both Rift Phases 1 and 2, and a broadly NW-SE-striking set that was only active during Rift Phase 2 (Fig. 2) (Whipp et al., 2014). The N-S-striking, basement-involved faults, which include the Svartav, Tusse, Vette and Øygarden fault systems, dip westward, are up to $>60 \mathrm{~km}$ long and have an average spacing of ca. 6-15 km (Fig. 2) (Whipp et al., 2014). These faults have up to 5 $\mathrm{km}$ of throw and define east-tilted half grabens filled with up to $3 \mathrm{~km}$ of Permo-Triassic sediments (e.g. Færseth, 1996; Bell et al., 2014; Whipp et al., 2014) (Fig. 2). In contrast, the NW-SE-striking faults are short $(2-10 \mathrm{~km})$, have low displacement $(30-100 \mathrm{~m})$, are closely-spaced $(0.5-5 \mathrm{~km})$, and are stratabound, being restricted to post-Upper Triassic stratigraphy (Fig. 2) (Whipp et al., 2014).

During the Triassic, the Horda Platform experienced continental conditions, resulting in the deposition of sandstones and mudstones (e.g. Hegre Group; Fig. 3) (Lervik, 2006). In the Early Jurassic to early Middle Jurassic, fluvio-deltaic-to-shallow-marine sediments of the Statfjord Formation, and Dunlin and Brent groups were deposited, during a period of tectonic quiescence and post-rift thermal subsidence following Rift Phase 1; Fig. 3) (e.g. Helland-Hansen et al., 1992). The diachronous onset of Rift Phase 2 was, in some places, coincident with deposition of the uppermost part of the Brent Group (Fig. 3) (e.g. Helland-Hansen et al., 1992). An overall deepening of the basin, which was associated with increased fault-controlled subsidence in Rift Phase 2, led to the deposition of the fully-marine Viking Group (Fig. 3). On the Horda Platform this consists of three stacked shallow marine clastic wedges, the Krossfjord, Fensfjord and Sognefjord formations, which are separated by major marine flooding events (Fig. 3) (e.g. Dreyer et al., 2005; Holgate et al., 2013). Basinwide flooding during the Late Kimmeridgian to Late Berriasian led to the deposition of marine mudstones of the Draupne Formation, which is capped by the Base Cretaceous Unconformity (BCU) (Fig. 3) (e.g. Rattey et al., 1993; Kyrkjebo et al., 2004). The clastic-dominated Jurassic stratigraphy was shallowly buried and thus likely weakly lithified at the onset of Rift Phase 2 extension, thus extensional forced folds and 'drag'-related folds are common in these units (Whipp et al., 2014). The BCU is overlain by deep-water clastics and carbonates (Cromer Knoll and Shetland groups), which 
are, in turn, overlain by a mud-dominated Cenozoic succession (Fig. 3) (e.g. Lepercq and Gaulier, 1996).

\section{Dataset and Methodology}

This study focuses on a $c a .350 \mathrm{~km}^{2}$ region around the Tusse Fault System, in an area covered by 2D and 3D time-migrated seismic reflection surveys (Fig. 2). The seismic data are zero-phase and reverse polarity (SEG convention) with seismic sections presented such that troughs (blue reflections) represent a downward increase in acoustic impedance. The 3D survey on which the majority of the fault and horizon interpretation is based has a vertical sampling interval of 2 milliseconds two-way time (ms TWT) and a record length of $3000 \mathrm{~ms}$ TWT, with inlines (NE-trending) and crosslines (NWtrending) spaced $18.75 \mathrm{~m}$ and $12.48 \mathrm{~m}$, respectively. Within the Top Triassic to Early Cretaceous interval of interest, the 3D seismic survey has a dominant frequency of $c a$. $50 \mathrm{~Hz}$, thus, by assuming an average seismic velocity of $2000 \mathrm{~m} / \mathrm{s}$ TWT we determine a vertical seismic resolution or 'limit of separability' (1/4 wavelength) of $c a .10 \mathrm{~m}$. The shallow burial of the Horda Platform means that the resolution of the 3D data is sufficient for detailed fault and horizon mapping. The 2D seismic lines are spaced approximately $1 \mathrm{~km}$, have a record length of 5000-7000 ms TWT, and are used mainly to constrain the thickness of the Permian-Triassic succession and the depth to acoustic basement (Fig. $2 a)$.

Eight key seismic surfaces, spanning the pre-, syn- and post-rift intervals, were identified based on stratal terminations and marked changes in seismic facies; these surfaces were mapped across the study area (Fig. 3) and were tied to eighteen wells using synthetic seismograms that helped constrain their ages (see Whipp et al., 2014). Faults, tiplines and branchlines were mapped on closelyspaced seismic sections, with care taken to accurately constrain fault-horizon cut-offs. Note that the term 'branchline' is used to define any line that joins two fault planes, irrespective of kinematic or age relationships between the faults. Styles of interaction and linkage between the non-colinear fault sets 
were identified and the geometry and kinematics of each style were examined in turn using evidence from TWT structure maps, isochron maps and seismic sections.

To determine how each interaction or linkage style evolved, we followed the approach of Nelson (2006) by defining the geometry of the faults, tiplines and branchlines before systematically examining throw patterns. First, to constrain how throw is distributed along-strike of key faults, throw-distance $(T-x)$ measurements were taken on different structural surfaces (e.g. Peacock and Sanderson, 1991). Second, to establish fault growth histories, throw-depth (T-z) plots were constructed, where throw across faulted horizons is plotted against the depth to the midpoint between the respective hanging-wall and footwall cut-offs (e.g. Muraoka and Kamata, 1983; Cartwright et al., 1995; Hongxing and Anderson, 2007; Baudon and Cartwright 2008a, b and c; Pochat et al., 2009). Third, throw strike projections (cf. Walsh and Watterson, 1991) were constructed for key faults to highlight the 3D distribution of throw at sites of interaction and linkage (see methods of Nelson, 2006; Baudon and Cartwright, 2008a, b and c). Throw values were converted from time (ms TWT) to depth (m) using a velocity model derived from time-depth curves from seven wells located within $6 \mathrm{~km}$ of the Tusse Fault. These wells show a simple best-fit second-order polynomial relationship between time and depth with an error margin of 50-120 $\mathrm{m}$ at the depth of interest (Fig. 2 and Appendix 1; see methods of Whipp et al., 2014; Bell et al., 2014). Patterns of throw on the faults do not vary significantly between the time and depth domains due to simple velocity structure in the overburden (cf. Baudon and Cartwright, 2008c; Conneally et al., 2014).

Unless otherwise stated in the text, the effect of fault-parallel folding on fault throw has been removed, such that total strain across the fault is calculated, whether accommodated by ductile (continuous) or brittle (discontinuous) deformation (e.g. Meyer et al., 2002; Long and Imber, 2010; Whipp et al., 2014). To achieve this, cut-offs were defined using an extrapolated line that follows the regional trend of the horizon prior to folding (e.g. Chapman and Meneilly, 1991; Mansfield and Cartwright, 1996; Wilson et al., 2013).

\section{Overview of the Northern Horda Platform Fault Network}


220 The Top Sognefjord TWT-structure map best illustrates the geometry of the Northern Horda Platform

221 fault network because it records deformation associated with both reactivated Permian-Triassic faults and new Middle Jurassic-Early Cretaceous faults (Fig. 4a). The Top Sognefjord horizon lies just below the Rift Phase 2 pre-rift /syn-rift contact. Deformation is dominated by the N-S-striking, Wdipping Tusse Fault, along with a series of shorter, predominantly NW-SE-striking faults that are present in both the hanging-wall and footwall of the Tusse Fault (Fig. 4a). These smaller faults show varying degrees and styles of mechanical interaction and/or linkage with the Tusse Fault, including examples that are: i) isolated and non-interacting; ii) abutting; iii) exploiting relay-breaching faults; and iv) retarded (Fig. 4a).

In plan view, the Tusse Fault is $>33 \mathrm{~km}$ long, curvilinear and has an overall N-S strike, although some small portions of the fault strike NE-SW or NW-SE (Fig. 4a). On dip-oriented crosssections, the fault is basement-rooted with the upper tip typically located in uppermost Cretaceous or Tertiary strata, being overlain by a west-facing monocline (Fig. 5a). Throw is highest at the Top Basement structural surface $(>1400 \mathrm{~ms})$, whereas at the Top Sognefjord structural surface, throw is smaller 120-700 m (90-520 ms TWT) (Fig. 5a). Throw does not vary smoothly along-strike of the Tusse Fault; instead, throw variations are 'step-like', and, locally, of large magnitude (up to $500 \mathrm{~m}$ ) (Fig. 4b). These 'steps' in throw correlate with locations where: i) NW-SE-striking 2nd-stage faults mechanically interact or link with the Tusse Fault; and ii) there are significant changes in the magnitude of ductile deformation, calculated by subtracting the true throw from the projected throw, along-strike of the Tusse Fault (Fig. 4; see sections 5 and 6).

Permian-Triassic and mid-Upper Jurassic to Lower Cretaceous strata thicken towards the Tusse Fault (Figs. 5a and 6 ) and $T-z$ profiles, taken at a range of locations along the Tusse Fault (including near sites of linkage with NW-SE-striking faults), show that, for both of these intervals of growth strata, throw increases with depth (Fig. 7a). These observations suggest the Tusse Fault was an active surface-breaking fault during Rift Phases 1 and 2 (see also Whipp et al., 2014). In contrast, the intervening Lower to mid-Upper Jurassic interval displays a relatively tabular geometry (Figs. $5 a$ 
and 6 ) and shows little variation in throw with depth (Fig. 7a). As such, we interpret that faulting in this interval is post-sedimentary and the Early to mid-Late Jurassic was a time of fault inactivity and burial (see also Whipp et al., 2014).

At the Top Sognefjord level, the broadly NW-SE-striking faults are typically 1-8 km long and are mainly linear in map view, although some faults in the south of the study area curve to strike N-S in the immediate hanging-wall of the Tusse Fault (Fig. 4a). Fault throw is typically 30-100 m (ca. 20$70 \mathrm{~ms}$ TWT) (Fig. 5b), but locally up to $300 \mathrm{~m}$ (ca. $210 \mathrm{~ms}$ TWT). On time-migrated cross-sections, the faults are planar with lower tips commonly located in uppermost Triassic sediments and upper tips located in the Cretaceous or lowermost Tertiary succession (Fig. 5). Thus it is unlikely that: i) structures or fabrics in the pre-Permian basement had any direct influence on the growth of the NWSE-striking faults; or ii) lower faults were simply reactivated to form the upper faults.

Lower Cretaceous strata thicken towards most but not all of the NW-SE-striking faults, suggesting some faults were active and broke surface during this time (Figs. 5 and 6 ). T-z profiles constructed for some of the NW-SE-striking faults are broadly symmetrical or slightly skewed towards the upper tip (cf. 'C-type' profiles of Muraoka and Kamata; 1983) (Fig. 7b). The points of maximum throw on $T-z$ profiles, often interpreted to represent the sites of fault nucleation of the fault (Mansfield and Cartwright, 1996; Cartwright et al., 1998; Hongxing and Anderson, 2007), are typically located at the Top Sognefjord (mid-Upper Jurassic) stratigraphic level, with throw decreasing to the upper and lower tips (Fig. 7b). We therefore interpret that the NW-SE-striking faults nucleated in the mid Upper Jurassic succession, were only active during Rift Phase 2, and developed mainly as a population of surface-breaking faults with some faults remaining blind (see also Whipp et al., 2014).

\section{Fault Interaction and Linkage Styles}

Here we examine variations in the fault tipline geometry, kinematics and throw patterns associated with each of the styles of interaction and linkage that occur between the Tusse Fault and $2^{\text {nd }}$-stage NW-SE-striking faults (F1-F16 on Fig 4). We initially examine mechanically and kinematically 
isolated $2^{\text {nd }}$-stage faults (section 5.1), and then examples where $2^{\text {nd }}$-stage faults abut against the Tusse Fault at relatively simple branchlines (section 5.2). We conclude by describing more complex styles, for example where 2nd-stage faults appear to reactivate 1st-stage relay-breaching faults (section 5.3) or show evidence of being mechanically retarded by the Tusse Fault (sections 5.3 and 5.4, respectively). For each of these styles, the plan-view structural style is described at the Upper Jurassic Top Sognefjord TWT structural surface. Furthermore, it is assumed that general characteristics (e.g. periods faults were active and/or surface-breaking, upper and lower tip locations, stratigraphic level of nucleation) of the Tusse Fault and the $2^{\text {nd }}$-stage NW-SE-striking faults (F1-F16) respectively, are the same as the type examples described in section 4. This section focuses on how interactions between the non-colinear faults influence throw patterns as well as tipline and branchline geometry.

\subsection{Mechanically and Kinematically Isolated Faults}

Fault F11 is representative of the numerous $2^{\text {nd }}$-stage NW-SE-striking normal faults that are isolated, that is, they show no evidence of interaction or linkage with other NW-SE-striking faults or the Tusse Fault. Fault F11 has a linear trace in map view, dips to the NE and lies $c a .7 \mathrm{~km}$ into the hangingwall of the Tusse Fault (Figs. $4 a, 5 c, 8 a$ ). The tipline of F11 is quasi-elliptical with a flat upper tipline located in the lowermost Tertiary succession (Fig. 8c) and a lower tipline located in the uppermost Triassic interval. Maximum fault height at the centre of the fault ellipse is $c a .980 \mathrm{~m}(c a .900 \mathrm{~ms}$ TWT) (Fig. 8c).

$T-x$ profiles are smooth and symmetrical, with throw highest at the centre of the fault (Fig. $8 b$ ). On the fault surface, throw contours are quasi-elliptical and show a 'bullseye' pattern, centred on a single throw maximum ( $c a .65-70 \mathrm{~m}$ or $50 \mathrm{~ms}$ TWT) that is located towards the upper centre of the fault surface, in Middle to Upper Jurassic strata (Fig. 8c). Throw decreases in all directions away from the throw maximum and towards the tipline, although higher throw gradients are observed towards the upper tip (Fig. 8c). This asymmetry is captured on a $T-z$ plot taken from the centre of the fault that is skewed towards the upper tip (Fig. 7b). There is minor thickening of the uppermost Jurassic and Cretaceous succession in the hangingwall of the fault. 
We interpret that the Rift Phase 2-related NW-SE-striking fault grew as an isolated structure based on the lack of any evidence of mechanical interaction or linkage with any other faults, and the gradual decrease in throw away from the centre of the fault surface (Fig. 8) (cf. Barnett et al., 1987;

Walsh and Watterson, 1989; Nicol et al., 1996). The position of maximum throw suggests that the fault nucleated in Middle to Upper Jurassic stratigraphy (Fig. 8b). Thickening of strata across the fault indicates that it was active and surface-breaking during the Late Jurassic and Cretaceous, an interpretation supported by the flat upper tipline and high throw gradients near the upper tip, both of which indicate that the upper tip was influenced by the free surface (Figs. 5c, $7 b$ and $8 c$ ) (cf. Peacock and Sanderson, 1991; Nicol et al., 1996; Childs et al, 2003; Baudon and Cartwright, 2008a, b and c).

\subsection{Abutting Fault Interactions}

Fault F7 is a typical example of 'Y-shaped' intersection where one of the $2^{\text {nd }}$-stage NW-SE-striking faults (F7), terminates ('abuts') against the Tusse Fault (Figs. 4a, 9a-b). Abutting interactions are the most common linkage style along the Tusse Fault, occurring in both its hangingwall (e.g. Fault F4, F14 and F16; Fig 4a) and footwall (e.g. Faults F5, F7 and F12; Fig 4a). Fault F7 lies in the footwall of the Tusse Fault, is NE-dipping and terminates against a NE-SW-striking portion of the Tusse Fault at branchline w-w' (Figs. 4a and 9). The footwall block of F7 is shared with the footwall of the Tusse Fault (Fig. 9b). Branchline w-w' plunges gently towards the NNE and has a height of $1100 \mathrm{~m}$ (ca. 970 ms TWT), which approximates to the maximum height of Fault F7 (Fig. 9b, d-e). In contrast to the isolated, non-interacting faults, the tipline of F7 is semi- rather than fully-elliptical due to the physical link with the Tusse Fault ( $c f$. Figs. $8 c$ and $9 e$ ).

At the Top Sognefjord surface, throw on Fault F7 is highest at branchline w-w' ( $c a .90 \mathrm{~m}$ or $70 \mathrm{~ms}$ TWT) and decreases down to $c a 30 \mathrm{~m}$ (23 ms TWT) $2.3 \mathrm{~km}$ away from the Tusse Fault (Fig. 9c). Along-strike of the Tusse Fault an abrupt southward increase in throw of $c a .90 \mathrm{~m}$ (70 ms TWT) is observed across branchline w-w' (Fig. 9d). The zone of higher throw corresponds with where the footwall of the Tusse Fault also lies in the footwall of Fault F7 (Fig. 9d). The strike-projected throw distribution on Fault F7 differs from that of isolated, non-interacting faults in two ways. Firstly, a 
single throw maximum, centred on Middle to Upper Jurassic stratigraphy, is located immediately adjacent to branchline w-w' rather than towards the centre of the fault, and secondly, throw contours are semi- rather than fully-elliptical (Fig. 9e). From the throw maximum at the branchline, throw decreases upwards, downwards and away from the branchline with the throw gradient being higher towards the upper tipline (Fig. 9e).

Fault F7 is one of the NW-SE-striking set and, as such, was active only during Rift Phase 2, as shown by the fault having a single throw maximum, and interpreted nucleation site, in post-RP1 Middle to Upper Jurassic stratigraphy. The location of the throw maximum on Fault F7 suggests the abutting fault nucleated at, or within a few hundred metres of branchline w-w', with the unrestricted lateral tip propagating SE into the footwall of the Tusse Fault and the other lateral tip being pinned by the Tusse Fault. Thickening in the hangingwalls of the Tusse Fault and Fault F7, as well as higher throw gradients towards their upper tips, indicates both faults were surface breaking during the Late Jurassic and Early Cretaceous. As F7 abuts against the Tusse Fault, that is, the Tusse Fault restricted the propagation of F7 into its hangingwall, it follows that F7 nucleated either at the same time or after the reactivation of the Tusse Fault. We note that the 'step' in throw on the Tusse Fault across branchline w-w' ( $c$. $90 \mathrm{~m}$ or 70 ms TWT) approximates the throw on Fault F7 near to the branchline (Figs $9 c$ and $d$ ). We suggest that the higher throw on the Tusse Fault to the south of the branchline is due to the uplifted Tusse Fault footwall having received an 'extra' component of uplift from the uplifted footwall of Fault F7 (i.e. local throw enhancement), whereas the lower throw to the north of the branchline is due to the effect of uplift in the footwall of the Tusse Fault being counteracted by subsidence of the hangingwall block of Fault F7 (i.e. local throw reduction).

\subsection{Reactivated Relay Fault Interactions}

Reactivated relay interactions are rare along the Tusse Fault, with Fault F1 being the only example (Figs. 4a, 10a and $b$ ). At this intersection the Tusse Fault consists of a $c a .1 .1 \mathrm{~km}$ long, NW-SEstriking, SW-dipping segment that links two major N-S-striking, W-dipping segments; based on this geometric arrangement, we infer that the SW-dipping segment formed to accommodate breaching of a 
relay zone developed between the two N-S-striking faults during Rift Phase 1 (Figs. 10a and b). This short NW-SE-striking part of the Tusse Fault plane is composite or 'shared' with part of the linear Fault F1, with portions of the F1 fault plane extending to the northwest and southeast of the composite plane (Figs. 10a and b). Two southwesterly-plunging branchlines ( $\mathrm{x}-\mathrm{x}^{\prime}$ and $\mathrm{y}-\mathrm{y}$ ') are developed on Fault F1 and bound the composite fault plane (Fig. 10). Of these branchlines, $\mathrm{x}-\mathrm{x}$ ' is located in the northwest where the northern, N-S-striking part of the Tusse Fault intersects Fault F1, and y-y' is located in the southeast where the southern N-S-striking part of the Tusse Fault intersects Fault F1 (Figs. $10 b$ and $d$ ). Portions of Fault F1 to the northwest and southeast of the composite fault plane, respectively, are semi-elliptical and have lower tiplines residing in the uppermost Triassic succession (Fig. 10d). However, the lower tipline of the composite fault plane, as with the Tusse Fault elsewhere, extends down into the basement (Fig. 10d).

On a $T-x$ plot at the Top Sognefjord structural surface (Fig. 10c), throw on Fault F1 increases from zero at the lateral tips to 50-80 m (37-55 ms TWT) at the branchlines with the Tusse Fault. On the N-S-striking components of the Tusse Fault, to the north and south of where its plane is shared with Fault F1, throw values reach up to $380 \mathrm{~m}$ (260 ms TWT) (Fig. 10c). In contrast, along the NWSE-striking composite plane, composite throw values are higher 430-490 m (280-330 ms TWT) with marked steps in throw coinciding with the locations of branchlines $\mathrm{x}-\mathrm{x}^{\prime}$ and $\mathrm{y}-\mathrm{y}$ ' (Fig. 10c), a trend also shown on strike-projected throw plots (Figs. 10d and e). A $T-z$ plot taken in the centre of the composite fault reveals a throw profile typical of the Tusse Fault, with throw decreasing steadily upwards in the Permian-Triassic and in the Upper Jurassic-to-Early Tertiary successions, and showing no significant variation with depth in the intervening Jurassic succession (Fig 7a). The throw distributions on portions of Fault F1 to the northwest and southeast of the composite plane, display semi-elliptical throw contours, with each portion having a throw maximum located adjacent to the composite plane and centred on Middle to Upper Jurassic stratigraphy (Fig. 10d). Throw decreases away from the maxima near the branchlines in the same way as for abutting $2^{\text {nd }}$-stage faults, with the throw gradients higher towards the upper rather than the lower tipline (cf. Figs. 9e and 10d).

We interpret that the composite fault and the N-S-striking segments of the Tusse Fault were both active during Rift Phases 1 and 2 and buried and inactive during the Early to mid-Late Jurassic; this is 
based on (i) the upward decrease in throw and the presence of growth beds in the Permian-Triassic and Upper Jurassic-Lower Cretaceous successions; and (ii) consistent throws with depth in the intervening Lower and Middle Jurassic successions (Figs. $7 a$ and 10e). Given their similar growth history but their differences in strike, we interpret that, by the end of Rift Phase 1, the NW-SEstriking composite fault had breached a relay that separated the two N-S-striking segments, thus linking the two. In contrast, the portions of Fault F1 lying to the northwest and southeast of the composite segment were only active during Rift Phase 2, as indicated by the presence of Upper Jurassic-Lower Cretaceous (but not Permian-Triassic) growth strata. Given that throw is highest on the composite NW-SE-striking fault segment and that the throw maxima on portions of Fault F1 outside of the composite fault lie immediately adjacent to the branchlines with the Tusse Fault (Figs. 10c-e), we propose that, during Rift Phase 2, the NW-SE-striking portion of the Tusse Fault, which previously represented a relay-breaching fault, was reactivated. This segment was exploited as a nucleation site for Fault F1 prior to the fault propagating away to the NW and SE. As such, the NWSE-striking composite fault (the 'reactivated relay-breaching fault') accommodated throw that accumulated on both the Tusse Fault and F1 during Rift Phase 2. We argue that the NW-SE-striking 'relay-breaching' fault was exploited as nucleation site of $2^{\text {nd }}$ stage faults during Rift Phase 2 due to it being: i) preferentially oriented with respect to the new local, possibly NE-SW extension direction; or ii) a releasing bend formed due to left-lateral oblique slip on the reactivated 1st-stage fault ( $c f$. Morley et al., 2004).

The interaction style described above shares some broad similarities with the 'synthetic trailing fault interaction' described by Nixon et al. (2014). For example, both examples are associated with a pre-existing (1st-stage) fault plane that displays locally high throw, bound by two branchlines associated with hangingwall and footwall segments (cf. Fig. 10 this study and Figs 15 and 16 in Nixon et al., 2014). However, a series of key geometric and kinematic observations suggest that the style of interaction documented here is in fact different to that documented by Nixon et al. (2014) for 'synthetic trailing faults'. The most critical observation is that 'synthetic trailing fault interactions' form as two faults in the hangingwall and footwall of a pre-existing fault propagate towards, link with (abut against), and eventually reactivate the pre-existing fault, thus resulting in a zone of locally high 
throw and the formation of a connecting 'trailing segment' between the abutting faults. In contrast, in the Horda Platform, it is the reactivated relay-breaching fault (or the 'trailing segment' of Nixon et al., 2014) that reactivates first during the 2 nd-stage of extension, propagating as a single fault into its footwall and hangingwall. Given this fundamental kinematic difference, and that the dominant influence on this interaction style is the reactivation of the relay-breaching fault inherited from Rift Phase 1 and its continued propagation, we term this a 'reactivated relay fault' interaction style.

\subsection{Hybrid and Retarding Fault Interactions}

Hybrid fault interactions are those that display evidence of more than one style of interaction or linkage. Here we examine a particularly well-imaged example of a hybrid interaction that occurs between the Tusse Fault and Fault F8. In plan view, at the Top Sognefjord structural surface, Fault F8 is linear and tips out $c a$. $200 \mathrm{~m}$ from the Tusse Fault (Figs. 11a and b). In the region between Fault F8 and the Tusse Fault a zone of intense ductile deformation is developed (Figs. 4a, 11a and b). In contrast, at the Top Brent level, Fault F8 is hard-linked and abuts against the Tusse Fault at branchline z-z'. Fault F8 downthrows to the SW, such that south of branchline $\mathrm{z}-\mathrm{z}^{\prime}$ the hangingwall block is shared with the Tusse Fault.

Away from the zone of ductile deformation ( $c a .3 \mathrm{~km}$ from the Tusse Fault), the dip-oriented geometry of Fault F8 is typical of that of the other NW-SE-striking faults (Fig. 5c). In cross-section the upper tipline resides in the lowermost Tertiary interval and has a sub-horizontal morphology, whereas the lower tipline, which is more poorly imaged, appears to be located in the Permian-Triassic succession (Figs. 5c and 11e). Although the WNW tip of Fault F8 lies outside of the study area, extrapolation of the tipline and strike-projected throw contours suggests the fault is semi-elliptical, a function of having a branchline with the Tusse Fault (Fig. 11e). This branchline only extends for 50\% of the height of Fault F8, with the upper tip lying between the Top Brent and Top Sognefjord horizons but instead is 'soft-linked' with the larger, pre-existing structure (Fig. 11e). 

of Fault F8 gradually increases towards the Tusse Fault (Fig. 11c). In contrast, true throw (solely brittle deformation) gradually increases up to a point ca. $1.3 \mathrm{~km}$ from the Tusse Fault before sharply decreasing to zero $c a .200 \mathrm{~m}$ from the Tusse Fault (Fig. 11c). A Top Sognefjord T-x plot along-strike of the Tusse Fault (Fig. 11d) highlights an abrupt southwards increase, a near doubling, of throw across the branchline with F8, that is, the transition from where the hangingwall of the Tusse Fault is associated with the footwall of F8 to the portion where the hangingwall of the Tusse Fault and the hangingwall of F8 are shared (Figs. $4 b$ and 11d). Furthermore, Fig. 11c illustrates striking variations in how throw is partitioned between ductile and brittle components across the intersection. First, the summed amplitude of folding associated with F8 (grey shading) increases from ca. $25 \mathrm{~m}$ (ca. $20 \mathrm{~ms}$ TWT) approximately $1.3 \mathrm{~km}$ from the Tusse Fault to $320 \mathrm{~m}$ ( $c a .220 \mathrm{~ms}$ TWT) at the intersection with the Tusse Fault (Fig. 11c). Second, the T-x plot along the Tusse Fault reveals a significant increase in the summed amplitude of folding from $0 \mathrm{~m}$ to $c a .300 \mathrm{~m}$ moving southwards across the branchline with F8 (Fig. 4b).

The throw distribution on Fault F8 shows a single maximum that is centred on Mid-to-Upper Jurassic stratigraphy (Fig. 11e) and is neither located in the centre of the fault, as with isolated, noninteracting faults, or immediately adjacent to the branchline with the Tusse Fault, as with abutting faults (cf. Figs $8 c$ and $9 e$ ). Instead, the throw maximum is lobate in shape and, although throw is high near the branchline, the maximum throw is centred $c a .1 .3 \mathrm{~km}$ into the hangingwall of the Tusse Fault (Fig 11e). Throw smoothly decreases away from throw maximum in all directions such that throw contours near the branchline are horizontal (Fig. 11e).

The location of the true throw maximum leads us to interpret that F8 nucleated $c a .1 .3 \mathrm{~km}$ into the hangingwall of the Tusse Fault in the Mid-to Late Jurassic succession before propagating to the WNW and ESE. It is likely that, as the ESE tip of Fault F8 approached the Tusse Fault, the relative dips of Tusse Fault and Fault F8, in combination with the tipline geometry of Fault F8 meant that the Fault F8 only abutted against, and locally linked with the Tusse Fault along a short branchline and at relatively deep structural levels (i.e. below the Top Sognefjord horizon) (Fig. 11e). In contrast, at and above the Top Sognefjord horizon, Fault F8 did not abut against, or develop a branchline with the 
464 Tusse Fault (Figs. 11a, b, $c$ and e). Instead, we interpret that the combination of the intense ductile 465 deformation ahead of the ESE tip of Fault F8 at shallow levels, the skew of true throw on Fault F8 towards the Tusse Fault and the high throw gradient near the branchline indicate that ESE-directed tip propagation in the shallow portion was mechanically retarded by the Tusse Fault (cf. Manighetti et al., 2001; Nelson, 2006; Nixon et al., 2014). Despite the lack of hard-linkage between the Tusse Fault and Fault F8 at the Top Sognefjord level and above, when projected throw (i.e. that which sums ductile and brittle deformation) is used to determine a Top Sognefjord $T-x$ profile along the Tusse Fault, the ductile deformation ahead of the ESE tip of Fault F8 ensures that a 'step' increase in throw towards the shared hangingwall block (Fig. 11d). Given that Fault F8 shows evidence of both abutting against, and being mechanically retarded by the Tusse Fault, this example has effectively been fossilised during the transition from one interaction style to another, capturing two discrete stages in the evolutionary sequence of fault intersections.

476

\section{Discussion}

\subsection{Styles of Fault Interaction and Linkage in Multiphase Rifts}

In this study, 2nd-stage faults interact with the reactivated Tusse Fault to varying extents; some faults are physically and kinematically isolated from the larger structure ( $c a .60 \%)$, some abut against it ( $c a$. $30 \%$ ) or show evidence of having been retarded by it, whereas others exploit and reactivate earlier relay zones (Figs. 4a, 8-11). The fault interactions observed from a natural multiphase system in this study are supported by findings from physical models as well as other natural systems (e.g. Bonini et al., 1997; Keep and McClay, 1997; Bellahsen et al., 2005; Henza et al., 2010; 2011). First, we note that reactivation of 1 st-stage faults is broadly synchronous with the nucleation of $2^{\text {nd }}$-stage faults, a characteristic observed in physical models specifically created to investigate how the growth of $2^{\text {nd }}-$ stage faults is influenced by the number and maturity of 1st-stage faults and changes in extension direction $\left(<45^{\circ}\right)$ (Henza et al. 2010; 2011). Second, our observation that some of the $2^{\text {nd }}$-stage faults 
nucleated at reactivated 1st-stage faults, is supported by a range of studies which suggest that preexisting faults can act as nucleation sites for $2^{\text {nd }}$-stage faults (Figs. 8-12) (e.g. Meyer et al., 2002; Walsh et al., 2002; Henza et al., 2010; 2011). Third, we observe 2nd-stage faults that abut against, or show evidence of having been retarded by the reactivated 1st-stage fault (e.g. F6-F8 and F12-F14; Fig. 4a) and some that curve into parallelism with the main structure when in close proximity (e.g. F15; Fig. 4a). These observations suggest the Tusse Fault has acted as mechanical barrier and perturbed the regional stress field, thus restricting and influencing the propagation of later faults ( $c f$. Færseth et al., 1997; Færseth and Ravnås, 1998; Bellahsen et al., 2005; Nelson, 2006; Henza et al., 2011; Nixon et al., 2014).

Although there are similarities between the fault interactions in this study and those described from physical modelling studies and other natural fault systems, there are also some differences. In particular, in models D and E in Henza et al. (2011), where 1st-stage faults are well-developed before the extension direction changes for the second rift phase, a high number of 2 nd-stage faults cross-cut 1st-stage faults. However, we see no evidence of $2^{\text {nd }}$-stage faults cutting across and offsetting the Tusse Fault (e.g. Fig 4a), which may be due to the restricted sample size of fault interactions in this study relative to that in the models of Henza et al. (2011). Another potential cause for the absence of cross-cutting interactions may be that, in our natural example, fault interactions were catalogued on the Top Sognefjord surface, an essentially 'intra-rift' surface (i.e. deposited between Rift Phase 1 and 2). In contrast, in the models of Henza et al. (2011), syn-rift layers were not added during either phase of extension, and hence fault interactions were catalogued on a true pre-rift surface. As such, the reactivated Tusse Fault had to propagate upwards through overlying intra-rift sediments, potentially reducing the opportunity for $2^{\text {nd }}$-stage faults to cross-cut it.

Based on map view geometry alone (Figs. $10 a$ and $b$ ), the reactivated relay fault interaction could be mistaken for a simple cross-cutting fault relationship. However, kinematic analysis reveals that, during Rift Phase 2, the NW-SE-striking relay-breaching fault developed in Rift Phase 1 was reactivated and exploited as a nucleation site for NW-SE-striking Fault F1, which propagated to the NW and SE, away from the 'composite' fault plane (Fig. 10). We demonstrate that the 1 st- and $2^{\text {nd }}-$ 
stage faults at the reactivated relay fault interaction were then active synchronously during Rift Phase 2 , such that the relay fault became a 'zone of shared throw'.

Given that the Tusse Fault was fully reactivated during Rift Phase 2, we do not document 2nd-stage faults cross-cutting and offsetting inactive 1st-stage structures (sensu Needham et al., 1996). Such interactions will be more common in multiphase rifts where the extension directions between the two rift phases are highly oblique $\left(>45^{\circ}\right)$, such that reactivation of 1 st-stage faults is not favoured (e.g. Nelson, 2006). We also speculate that, in general, a higher frequency of fault bends and relay-breaching faults along 1st-stage faults, in combination with a favourable extension direction in the second phase of extension, may result in more potential nucleation sites for 2nd-stage faults ( $c f$. Lezzar et al., 2002; Bellahsen et al, 2005; 2006).

\subsection{The Geometry and Throw Patterns of Faults in Multiphase Rifts}

We have documented the styles of interaction that occur between non-colinear faults in a multiphase fault network. In particular, we have demonstrated that a wide range of interaction styles and patterns of throw develop in association with non-colinear faults, with the key relationships synthesised in Figure 12. The tipline geometries of $2^{\text {nd }}$-stage, non-colinear faults that interact with 1 st-stage faults may vary depending on the interaction style and whether the faults are blind or surface-breaking (Fig. 12). Flat upper tiplines are typically associated with surface-breaking faults and convex-upward upper tiplines are associated with blind faults (Fig. 12) (e.g. Nicol et al., 1996; Childs et al. 2003; Baudon and Cartwright, 2008). In the simplest scenario in which faults are blind, where a 2nd-stage fault nucleates and propagates in isolation from a 1st-stage fault, both faults will tend towards having elliptical tiplines (Fig. 12a). In the case that both faults are free from lithological restriction, both faults should theoretically tend towards an aspect ratio of 2 (e.g. Nicol et al., 1996). In contrast, where a 2nd-stage fault is laterally restricted by a pre-existing fault (Figs. $12 b$ and $c$ ), the geometry of the 2nd-stage fault tipline can be highly variable, although typically more asymmetric in form and, in the case that the faults are blind, should have an aspect ratio <2. In cases where a 2nd-stage fault 
nucleates at a pre-existing fault, the tipline geometry of the 2 nd-stage fault will be semi-elliptical, due to the physical link with the pre-existing fault (Figs. 12d and e).

If we consider the characteristics of a $2 \mathrm{D} T-x$ profile taken along-strike of a reactivated 1ststage fault (e.g. Fig. 4b), it can be seen that throw does not vary smoothly across the fault surface; rather, it is characterised by 'steps' in throw where the Tusse Fault is influenced by physical or kinematic interactions with 2 nd-stage faults. Thus, $T-x$ profiles along reactivated structures that are hard or soft-linked to newly-formed faults will differ from those from faults developed in response to the growth of a single fault segment (cf. Watterson, 1986; Barnett et al., 1987; Nicol et al., 1996; Needham et al., 1996) or the linkage of smaller precursor segments ( $c f$. Anders and Schlische, 1994; McLeod et al., 2000; Young et al., 2001). We also note how the magnitude of ductile deformation along-strike of a reactivated 1st-stage fault also displays 'steps' in the profile, correlating with locations where $2^{\text {nd }}$-stage faults soft or hard-link with the 1st-stage fault (Fig. $4 b$ ). Furthermore, the way in which throw is partitioned between interacting faults and across branchlines is dependent on the interaction style (Figs. 8-12). For example, where a 2nd-stage fault is isolated from, and not laterally restricted by a 1 st-stage fault, the throw maximum on the $2^{\text {nd }}$-stage fault is located towards the fault centre, with throw decreasing smoothly and linearly towards the tips (Figs. 8 and 12a). Where a 2nd-stage fault nucleates at and propagates away from a pre-existing structure, either into its hanging-wall or footwall, the mutual hanging-wall or footwall block experiences an additional component of subsidence or uplift, respectively (Figs. 9, $12 d$ and e). On the 1st-stage fault, this is expressed by a sharp increase in the throw towards the shared hangingwall or footwall block (Figs. $12 d$ and e) (sensu Nelson, 2006; Nixon et al., 2014). The 2nd-stage fault will be bound by a steep branchline, along which the maximum throw occurs such that throw contours are semi-elliptical (Figs. $12 d$ and $e$ ). In cases where the 2 nd-stage fault grows towards and is retarded by the 1 st-stage fault, the throw maximum on the 2nd-stage fault will be located towards the laterally-restricted portion of the fault, with high throw gradients developing near the restricted tip (Fig. 12b) (sensu Manighetti et al., 2001; Nixon et al. 2014).

The individual styles of fault interaction and linkage captured in this study, and those of Nixon et al. (2014), show discrete stages of interaction development. However, observations from 
571 physical modelling studies (e.g. Henza et al., 2010; 2011) indicate that fault intersection development 572 is a dynamic process, involving a gradual transition from one style to another. For example, 2nd-stage

573 faults which nucleate away from 1st-stage faults and grow initially as isolated 2nd-stage faults (e.g. 574 Figs. 8 and 12a), may propagate towards and be retarded by the 1st-stage fault resulting in higher 575 throw gradients towards the retarded tip (e.g. Figs. 11 and 12b) (sensu Manighetti et al., 2001; Nixon et al. 2014) prior to hard-linking with, and abutting against, the 1st-stage fault (e.g. Figs. 9 and 12c) (see also Nelson et al., 2006). This study suggests that abutting faults are unlikely to evolve to crosscut the earlier fault; in this study, cross-cutting is restricted to a breached fault segment boundary along-strike of the Tusse Fault (cf. Nelson, 2006). In contrast, in the case of 2nd-stage faults that nucleate at and propagate away from 1st-stage faults (Figs. $12 \mathrm{~d}$ and e), the branchline will be formed relatively early, and the style of interaction at the abutting tip would not change once the full branchline is developed.

\subsection{Implications for the Evolution of Multiphase Rift Fault Networks}

In the Northern Horda Platform both N-S- and NW-SE-striking faults were active synchronously during Rift Phase 2, even at complex intersections. It is thus likely that at least one, or possibly both, of these fault sets experienced oblique slip. Our simplest and preferred explanation is that, at least locally within the study area, the extension direction during Rift Phase 2 was reoriented to be NE-SW, sub-perpendicular to the strike of the majority of the NW-SE-striking faults; if true, this implies that the N-S-striking Tusse Fault may have been reactivated obliquely with a left-lateral sense of slip. The strike-parallel component of any oblique slip is likely to have been fairly low as no strong evidence of flower structures or laterally offset markers is noted in the 3D volume. In contrast, the observation of growth strata and vertical fault throw for the vast majority of faults in the array is evidence for a significant amount of fault activity with a dip-slip component.

We have developed a conceptual model highlighting the key characteristics of multiphase rift fault networks, drawing on observations from the northern Horda Platform, other natural rift fault networks, and physical models (Fig. 13). By comparing figures 1 and 13, the significant differences 
between non-colinear fault networks developed during single-phase and multiphase extension become clear. For example, non-colinear faults are more pervasive in a multiphase network than would typically occur in a single-phase rift, and multiphase rift fault networks are more complex and connected, being influenced by a larger number of fault interactions and wider range of interaction or linkage styles ( $c f$. Figs 1 and 13). However, we can also see how individual non-colinear fault relationships developed in single- and multiphase rift networks can appear geometrically similar ( $c f$. Figs 1 and 13). For example, abutting faults developed during a second phase of extension are, when viewed individually, indistinguishable from splay faults and release faults developed during a single rift phase; all strike oblique to the main fault and tend to have a nucleation site and throw maximum near the main fault (e.g. Baudon et al., 2008a; Nixon et al. 2014) (cf. Figs 1 and 13). We suggest that, determining the origin of non-colinear faults requires knowledge of the relative timing of fault activity. In natural fault networks, this knowledge is best gained by studying data-rich areas where borehole-constrained 3D seismic data allows constraints to be placed on the age of growth strata adjacent to the faults. If the non-colinear fault in question is an abutting fault developed during a second rift phase rather than a splay fault developed during a single rift phase, activity on this fault should correspond to the second rift phase and hence post-date the initial activity on the main fault. In addition to determining the relative timing of fault activity, the location of the interaction with regards to the tips and segment centres of 1st-stage faults and/or the relative abundance of the interaction type within the network can also help distinguish between different causal mechanisms. For example: i) relatively small splay faults will likely cluster at the tips of the main faults; ii) release faults will tend to be located at sites of throw maxima and minima along-strike of the main faults; and iii) abutting faults developed due to a second phase of extension will be part of a pervasive non-colinear array (e.g. Reeve et al., 2015).

Overall, the approach to the analysis of fault interactions applied in this study and the key findings are applicable to any rift setting characterised by dip-slip non-colinear faults. We present new insights into the geometries, throw patterns and kinematics of faults associated with different fault interaction styles in a multiphase rift, providing a basis for future studies examining the how singlephase and multiphase rift fault networks evolve. 


\section{Conclusions}

Analysis of a 3D borehole-constrained seismic dataset from the northern Horda Platform reveals a network of non-colinear faults that developed due to multiple phases of extension. The fault network consists of a high-throw N-S-striking fault which was active during Rift Phases 1 and 2 and a series of shorter, NW-SE-striking faults which were only active during Rift Phase 2. We show that:

1. In the northern Horda Platform fault network, a multiphase network that experienced a different local extension direction in each rift phase, non-colinear faults are more pervasive than in networks developed during a single phase of extension. Furthermore, the northern Horda Platform network is more complex and connected than a typical single-phase network, being influenced by a higher frequency of interactions between $1^{\text {st }}$ and 2 nd-stage faults .

2. A wide range of styles of fault interaction can occur between 1 st- and $2^{\text {nd }}$-stage faults in multiphase rift fault networks that have experienced a different local extension direction in each phase. At the Top Sognefjord structural level in the northern Horda Platform network we document $2^{\text {nd }}$-stage faults that are isolated from the 1st-stage fault ( $c a .60 \%$ ), abut against it (ca. 30\%), or those that exploit breached relay zones along the Tusse Fault or show evidence of the propagation of the fault having been retarded by it ( $\mathrm{ca}$. 10\% combined).

3. In multiphase rift fault networks, the typical geometries of fault tiplines and the distribution of throw on fault surfaces are highly-variable, being controlled to a large extent by the style of interaction between 1 st-stage and $2^{\text {nd }}$-stage faults. In particular we note how: i) the tiplines of many $2^{\text {nd }}$-stage faults are semi-elliptical due to the development of branchlines at sites of intersection with 1st-stage faults; ii) the distribution of throw on reactivated 1st-stage faults will be modified in a predictable manner if they are intersected or influenced by 2 nd-stage faults; iii) pre-existing faults can act as sites of nucleation for 2nd-stage faults as well as mechanical barriers that restrict or alter the propagation pathways of $2^{\text {nd }}$-stage faults; and iv) 

preferential nucleation sites for 2nd-stage faults.

4. The observation of a $2^{\text {nd }}$-stage fault that shows evidence of concurrently abutting against, and being mechanically retarded by a 1st-stage fault indicates fault interactions are not static and transition from one style to another. For example, $2^{\text {nd }}$-stage faults that nucleate away from, and propagate towards a 1st-stage fault may initially be isolated, before being mechanically retarded by, and eventually abutting and hard-linking with the 1st-stage fault.

Overall, we highlight how it is important to integrate borehole-constrained 3D seismic data with a systematic approach to the analysis of fault geometry and throw distributions in a fault network. This approach will allow interpreters greater confidence in mapping fault intersections in seismic datasets that lack clear imaging of faults and their geometric relationships, as well as in determining whether non-colinear fault networks developed during single- or multiple phases of rifting.

666

\section{Acknowledgements}

We thank Craig Magee, Casey Nixon, Atle Rotevatn and Haakon Fossen for constructive discussions during this project, and Alissa Henza and an anonymous reviewer for constructive reviews. We thank Nancy Cottington for help with figure editing. Schlumberger are thanked for providing an academic license for Petrel. This contribution forms part of the MultiRift Project funded by the Research Council of Norway (Project number 215591/E30) and Statoil to the University of Bergen and partners Imperial College, University of Manchester and University of Oslo. We also thank Statoil and NPD for providing access to seismic and well data. Statoil are thanked for permission to publish the results of this study. Conclusions from this paper do not necessarily reflect the views of Statoil or partners.

\section{Figure Captions}

Figure 1: Block model showing simple large-scale co-linear faults developed during a single-phase of rifting as well as the typical locations of any non-colinear faults that may develop (RP1 $=$ rift phase 1 , arrows indicate extension direction)

Figure 2: (a) Principal tectonic structures of the northern North Sea, after Færseth (1996) and Bell et al., (2014). The Horda Platform (HP), the focus of this study is outlined in red and the location of the regional interpretation shown in Figure 1c is shown by a bold black line. (b) Map showing the noncolinear fault sets in the northern Horda Platform fault array, colour-coded to highlight which faults 
were active in Rift Phase 1 (Permian-Triassic) and Rift Phase 2 (Late Jurassic - Cretaceous) (after Whipp et al., (2014)). (c) Regional interpretation of the structure of the northern North Sea after Færseth (1996).

Figure 3: Stratigraphic framework with a synthetic seismogram for well 31/6-6, showing the ages and representative lithologies of the key Groups and Formations in the Horda Platform along with key seismic stratigraphic markers (after Faerseth (1996) and Whipp et al., (2014) and modified from Bell et al., (2014)). Tectonic events based on the timing of activity of the Tusse Fault and nearby structures (after Whipp et al.,2014). A representative section of seismic reflection data from a 2D survey is shown to illustrate the typical seismic stratigraphy in the area. Colour coding of the seismic stratigraphic marker horizons and megasequences is continued throughout. $\mathrm{P}=\mathrm{Period}$ and $\mathrm{E}=\mathrm{Epoch}$. $\mathrm{TD}=$ Growth and deflation of the central North Sea thermal dome. *The timing of the initiation and cessation of Syn-Rift Phase 2 is diachronous across the Horda Platform (see Bell et al., 2014 for more details).

Figure 4: (a) TWT structure map of Top Sognefjord Fm with key faults labelled. (b) $T-x$ plot and distribution of ductile deformation (summed fold amplitudes) along-strike of the Tusse Fault system. Note the 'steps' in throw at sites of interaction with NW-SE-striking faults and how throw and degree of ductile deformation correlate along-strike of the Tusse Fault.

Figure 5: Series of seismic profiles and geoseismic sections illustrating key structural characteristics of the Tusse Fault system and the NW-SE-striking faults (locations of sections shown in Fig. 4a). (a) Seismic section and geoseismic section oriented orthogonal to the Tusse Fault system in the south of the study area. (b) Seismic section and geoseismic section oriented orthogonal to the Tusse Fault system in the north of the study area. (c) Seismic section and geoseismic section oriented orthogonal to a series of NW-SE-striking faults in the study area.

Figure 6: TWT-thickness maps for a series of stratigraphic intervals: (a) Permian-Triassic (Rift Phase 1), (b) Lower Jurassic to mid Upper Jurassic (intra-rift cessation) and (c) mid Upper Jurassic and Cretaceous (Rift Phase 2). Note how thickening across the Tusse Fault is observed only in (a) and (c).

Figure 7: (a) $T-z$ plots taken at various locations along the N-S-striking Tusse Fault and b) $T-z$ plots taken from various NW-SE-striking faults. Note that the locations of the plots in a) and b) are marked by stars on Fig 4a. These plots provide evidence that the Tusse Fault was active during Rift Phases 1 and 2 whereas NW-SE-striking faults only initiated during Rift Phase 2 (see text for more details).

Figure 8: Quantitative analysis of the isolated, non-interacting NW-SE-striking Fault F11. (a) Oblique view at the Top Sognefjord structural surface, image taken looking SE (V.E x5). (b) $T-x$ profile along Fault F11 at the Top Triassic and Top Sognefjord structural surfaces, with the highest throw located towards the centre of Fault F11. (c) Strike-projected throw distribution in ms TWT of Fault F11 with no vertical exaggeration. A single throw maximum is located towards the upper centre of the fault and throw contours are broadly elliptical. Projected fault cut-offs of key seismic stratigraphic horizons are shown with solid lines marking hanging-wall cut-offs and dashed lines footwall cut-offs (continued in Figures 9-11).

Figure 9: Quantitative analysis of the 'abutting' interaction between the Tusse Fault and Fault F7. (a) plan and (b) oblique views of the interaction at the Top Sognefjord structural surface (V.E x5). (c) T-x profile along Fault F7 at the Top Sognefjord horizon. (d) N-S $T-x$ profile along the Tusse Fault near branchline w-w' with Fault F7 at the Top Sognefjord horizon. Note the step-like increase in throw immediately south of branchline w-w' in the region of the mutual footwall. Strike-projected throw distribution in ms TWT on abutting Fault F7 with no vertical exaggeration. The tipline and throw contours are semi-elliptical with a single maximum located near the branchline.

Figure 10: Quantitative analysis of the reactivated relay interaction between the Tusse Fault and Fault F1. (a) Plan and (b) oblique views of the intersection at the Top Sognefjord horizon (V.E x5). (c) T-x profile along both faults at the Top Sognefjord structural surface. Note the higher throw between 
branchlines $x-x^{\prime}$ and $y-y^{\prime}$ in the portion of the fault plane that is shared with the Tusse Fault. (d) Strike-projected throw distribution in ms TWT of Fault F1 with no vertical exaggeration. The highest throw is located between branchlines $x-x^{\prime}$ and $y-y$ '. On the portions of Fault F1 either side of branchlines $x-x^{\prime}$ and $y-y$ ', fault throw are highest nearer the branchline and throw contours are semielliptical. (e) Strike-projected throw distribution in ms TWT of the Tusse Fault with no vertical exaggeration. Throw is highest between branchlines $x-x$ ' and $y-y$ '.

Figure 11: Quantitative analysis of the interaction between the Tusse Fault and Fault F8, a 'hybrid' interaction that shows evidence of both abutment and retardation. (a) plan and (b) oblique views of the intersection at the Top Sognefjord horizon (V.E x5). (c) $T$ - $x$ profile showing true throw along Fault F8 at the Top Brent horizon and both the true throw and projected throw along Fault F8 at the Top Sognefjord horizon; the true throw at the Top Sognefjord horizon is skewed towards the Tusse Fault suggesting the Tusse Fault has retarded the propagation of F8. (d) N-S T-x profile showing projected throw at the Top Sognefjord structural surface along the Tusse Fault near 'apparent' branchline z-z' with F8. Note the step-like increase in throw immediately south of the 'apparent' branchline z-z' in the region of the mutual hangingwall block. Strike-projected throw distribution in ms TWT of Fault F8 with no vertical exaggeration. Note: i) the short branchline that marks the abutment of F8 against the Tusse Fault; and ii) the area above the short branchline marked by ductile deformation is interpreted to represent 'retardation' of Fault F8 by the Tusse Fault.

Figure 12: Conceptual models showing how different fault interaction styles influence fault tipline geometry and throw patterns in multiphase rifts. Colour-coding of throw projections: purple represents lowest throw; blue, yellow and orange represent increasing respective throw amounts and red represents the highest throw.

Figure 13: Conceptual model fault network in a multiphase rift showing typical locations of, and styles of interaction between non-colinear faults. The model assumes that the extension direction in Rift Phases 1 and 2 are different and that faults developed in Rift Phase 1 are reactivated during Rift Phase 2. $(\mathrm{RP} 1=$ rift phase 1 , resulting in the formation of faults outlined in red; RP2 $=$ Rift Phase 2, resulting in faults outlined in blue).

Appendix 1 - Time-depth plots for seven key wells in close proximity to the Tusse Fault and a bestfit trendline which was used for depth conversion.

\section{References}

Aydin, A., Reches, Z.E., 1982. Number and orientation of fault sets in the field and in experiments. Geology 10, 107-112.

Bailey, W., Walsh, J., Manzocchi, T., 2005. Fault populations, strain distribution and basement fault reactivation in the East Pennines Coalfield, UK. Journal of Structural Geology 27, 913-928.

Barnett, J.A., Mortimer, J., Rippon, J.H., Walsh, J.J., Watterson, J., 1987. Displacement geometry in the volume containing a single normal fault. AAPG Bulletin 71, 925-937.

Bartholomew, I., Peters, J., Powell, C., 1993. Regional structural evolution of the North Sea: oblique slip and the reactivation of basement lineaments, Geological Society, London, Petroleum Geology Conference series. Geological Society of London 4, 1109-1122.

Baudon, C., Cartwright, J., 2008a. Early stage evolution of growth faults: 3D seismic insights from the Levant Basin, Eastern Mediterranean. Journal of Structural Geology 30, 888-898.

Baudon, C., Cartwright, J., 2008b. The kinematics of reactivation of normal faults using high resolution throw mapping. Journal of Structural Geology 30, 1072-1084. 
Baudon, C., Cartwright, J.A., 2008c. 3D seismic characterisation of an array of blind normal faults in the Levant Basin, Eastern Mediterranean. Journal of Structural Geology 30, 746-760.

Bell, R.E., Jackson, C.A.L., Whipp, P.S., Clements, B., 2014. Strain migration during multiphase extension: Observations from the northern North Sea. Tectonics. 33, 1936-1963.

Bellahsen, N., Daniel, J.M., 2005. Fault reactivation control on normal fault growth: an experimental study. Journal of Structural Geology 27, 769-780.

Bellahsen, N., Fournier, M., d'Acremont, E., Leroy, S., Daniel, J., 2006. Fault reactivation and rift localization: Northeastern Gulf of Aden margin. Tectonics 25, TC1007.

Bonini, M., Souriot, T., Boccaletti, M., Brun, J.P., 1997. Successive orthogonal and oblique extension episodes in a rift zone: Laboratory experiments with application to the Ethiopian Rift. Tectonics 16, 347-362.

Brun, J.-P., Tron, V., 1993. Development of the North Viking Graben: inferences from laboratory modelling. Sedimentary Geology 86, 31-51.

Burgmann, R., Pollard, D.D., Martel, S.J., 1994. Slip distributions on faults: effects of stress gradients, inelastic deformation, heterogeneous host-rock stiffness, and fault interaction. Journal of Structural Geology 16, 16751690.

Cartwright, J.A., Lonergan, L., 1996. Volumetric contraction during the compaction of mudrocks: A mechanism for the development of regional-scale polygonal fault systems. Basin Research 8, 183-193.

Cartwright, J.A., Dewhurst, D., 1998. Layer-bound compaction faults in fine-grained sediments." Geological Society of America Bulletin 110(10): 1242-1257.

Cartwright, J.A., Mansfield, C.S., 1998. Lateral displacement variation and lateral tip geometry of normal faults in the Canyonlands National Park, Utah. Journal of Structural Geology 20, 3-19.

Cartwright, J.A., Trudgill, B.D., Mansfield, C.S., 1995. Fault growth by segment linkage: an explanation for scatter in maximum displacement and trace length data from the Canyonlands Grabens of SE Utah. Journal of Structural Geology 17, 1319-1326.

Chapman, T., Meneilly, A., 1991. The displacement patterns associated with a reverse-reactivated, normal growth fault. Geological Society, London, Special Publications 56, 183-191.

Chattopadhyay, A., Chakra, M., 2012. Influence of pre-existing pervasive fabrics on fault patterns during orthogonal and oblique rifting: An experimental approach. Marine and Petroleum Geology.

Childs, C., Nicol, A., Walsh, J.J., Watterson, J., 2003. The growth and propagation of synsedimentary faults. Journal of Structural Geology 25, 633-648.

Conneally, J., Childs, C., and Walsh, J.J., 2014. Contrasting origins of breached relay zone geometries. Journal of Structural Geology 58, 59-68.

Corti, G., 2004. Centrifuge modelling of the influence of crustal fabrics on the development of transfer zones: Insights into the mechanics of continental rifting architecture. Tectonophysics 384, 191-208.

Corti, G., van Wijk, J., Cloetingh, S., Morley, C.K., 2007. Tectonic inheritance and continental rift architecture: Numerical and analogue models of the East African Rift system. Tectonics 26.

Coward, M., Dewey, J., Hempton, M., Holroyd, J., 2003. Tectonic evolution. The millennium atlas: Petroleum geology of the central and northern North Sea, 17-33. 
Cowie, P.A., Underhill, J.R., Behn, M.D., Lin, J., Gill, C.E., 2005. Spatio-temporal evolution of strain accumulation derived from multi-scale observations of Late Jurassic rifting in the northern North Sea: A critical test of models

for lithospheric extension. Earth and Planetary Science Letters 234, 401-419.

Davies, R., Turner, J., Underhill, J., 2001. Sequential dip-slip fault movement during rifting: a new model for the evolution of the Jurassic trilete North Sea rift system. Petroleum Geoscience 7, 371-388.

Dawers, N.H., Underhill, J.R., 2000. The role of fault interaction and linkage in controlling synrift stratigraphic sequences: late Jurassic, Statfjord East Area, northern North Sea. AAPG Bulletin 84, 45.

Destro, N., 1995. Release fault: A variety of cross fault in linked extensional fault systems, in the Sergipe-Alagoas Basin, NE Brazil. Journal of Structural Geology 17, 615-629.

Doré, A., Lundin, E., Fichler, C., Olesen, O., 1997. Patterns of basement structure and reactivation along the NE Atlantic margin. Journal of the Geological Society 154, 85-92.

Dreyer, T., Whitaker, M., Dexter, J., Flesche, H., Larsen, E., 2005. From spit system to tide-dominated delta: integrated reservoir model of the Upper Jurassic Sognefjord Formation on the Troll West Field, Geological Society, London, Petroleum Geology Conference series. Geological Society of London, pp. 423-448.

Færseth, R., 1996. Interaction of Permo-Triassic and Jurassic extensional fault-blocks during the development of the northern North Sea. Journal of the Geological Society 153, 931-944.

Færseth, R.B., Ravnås, R., 1998. Evolution of the Oseberg Fault-Block in context of the northern North Sea structural framework. Marine and Petroleum Geology 15, 467-490.

Fossen, H., 1992. The role of extensional tectonics in the Caledonides of south Norway. Journal of structural geology 14, 1033-1046.

Gawthorpe, R., Leeder, M., 2000. Tectono-sedimentary evolution of active extensional basins. Basin Research 12, 195-218.

Glennie, K.W. (1987). Outline of North Sea History and structural framework. In: Introduction to the Petroleum Geology of the North Sea. 3rd Edition. Blackwell Scientific Publications, Oxford 34-77

Helland-Hansen, W., Ashton, M., Lømo, L., Steel, R., 1992. Advance and retreat of the Brent delta: recent contributions to the depositional model. Geological Society, London, Special Publications 61, 109-127.

Henza, A.A., Withjack, M.O., Schlische, R.W., 2010. Normal-fault development during two phases of non-coaxial extension: An experimental study. Journal of Structural Geology 32, 1656-1667.

Henza, A.A., Withjack, M.O., Schlische, R.W., 2011. How do the properties of a pre-existing normal-fault population influence fault development during a subsequent phase of extension? Journal of Structural Geology 33, 1312-1324.

Holgate, N.E., Jackson, C.A.-L., Hampson, G.J., Dreyer, T., 2013. Sedimentology and sequence stratigraphy of the Middle-upper Jurassic Krossfjord and Fensfjord formations, troll Field, northern north Sea. Petroleum Geoscience 19, 237-258.

Hongxing, G., Anderson, J.K., Fault Throw Profile and Kinematics of Normal Fault.-Conceptual Models and Geologic Examples. 2007. Geological Journal of China Universities. 13, 75-88.

Imber, J., Holdsworth, R., McCaffrey, K., Wilson, R., Jones, R., England, R., Gjeldvik, G., 2005. Early Tertiary sinistral transpression and fault reactivation in the western Vøring Basin, Norwegian Sea: Implications for hydrocarbon exploration and pre-breakup deformation in ocean margin basins. AAPG bulletin 89, 1043-1069.

Keep, M., McClay, K., 1997. Analogue modelling of multiphase rift systems. Tectonophysics 273, 239-270. 
Knudsen, B.-E., Liljedahl, T., Midbøe, P., Søderstrøm, B., 1997. Oblique rifting and sequential faulting in the Jurassic

development of the northern North Sea. Journal of Structural Geology 19, 1285-1302.

Kornsawan, A., Morley, C.K., 2002. The origin and evolution of complex transfer zones (graben shifts) in conjugate fault systems around the Funan Field, Pattani Basin, Gulf of Thailand. Journal of Structural Geology 24, 435-449.

Krantz, R.W., 1989. Orthorhombic fault patterns: The odd axis model and slip vector orientations. Tectonics 8, 483495.

Kyrkjebø, R., Gabrielsen, R., Faleide, J., 2004. Unconformities related to the Jurassic-Cretaceous synrift-post-rift transition of the northern North Sea. Journal of the Geological Society 161, 1-17.

Lepercq, J.-Y., Gaulier, J.-M., 1996. Two-stage rifting in the North Viking Graben area (North Sea): inferences from a new three-dimensional subsidence analysis. Marine and Petroleum Geology 13, 129-148.

Lervik, K.-S, 2006. Triassic lithostratigraphy of the northern North Sea Basin. Norsk Geologisk Tidsskrift 86, 93-116.

Lezzar, K.E., Tiercelin, J.-J., Le Turdu, C., Cohen, A.S., Reynolds, D.J., Le Gall, B., Scholz, C.A., 2002. Control of normal fault interaction on the distribution of major Neogene sedimentary depocenters, Lake Tanganyika, East African rift. AAPG Bulletin 86, 1027-1060.

Long, J., Imber, J., 2010. Geometrically coherent continuous deformation in the volume surrounding a seismically imaged normal fault-array. Journal of Structural Geology 32, 222-234.

Maerten, L., Gillespie, P., Pollard, D.D., 2002. Effects of local stress perturbation on secondary fault development. Journal of Structural Geology 24, 145-153.

Maerten, L., Willemse, E.J., Pollard, D.D., Rawnsley, K., 1999. Slip distributions on intersecting normal faults. Journal of Structural Geology 21, 259-272.

Manighetti, I., King, G., Gaudemer, Y., 2001. Slip accumulation and lateral propagation of active. Journal of Geophysical Research 106, 13,667-13,696.

Mansfield, C.S., Cartwright, J.A., 1996. High resolution fault displacement mapping from three-dimensional seismic data: evidence for dip linkage during fault growth. Journal of Structural Geology 18, 249-263.

McClay, K.R., White, M.J., 1995. Analogue modelling of orthogonal and oblique rifting. Marine and Petroleum Geology 12, 137-151.

McLeod, A.E., Underhill, J.R., Davies, S.J., Dawers, N.H., 2002. The influence of fault array evolution on synrift sedimentation patterns: Controls on deposition in the Strathspey-Brent-Statfjord half graben, northern North Sea: AAPG Bulletin 86, 1061-1094.

Meyer, V., Nicol, A., Childs, C., Walsh, J., Watterson, J., 2002. Progressive localisation of strain during the evolution of a normal fault population. Journal of Structural Geology 24, 1215-1231.

Morley, C., 2007. Variations in late Cenozoic-Recent strike-slip and oblique-extensional geometries, within Indochina: The influence of pre-existing fabrics. Journal of Structural Geology 29, 36-58.

Morley, C., Haranya, C., Phoosongsee, W., Pongwapee, S., Kornsawan, A., Wonganan, N., 2004. Activation of rift oblique and rift parallel pre-existing fabrics during extension and their effect on deformation style: examples from the rifts of Thailand. Journal of Structural Geology 26, 1803-1829.

Muraoka, H., Kamata, H., 1983. Displacement distribution along minor fault traces. Journal of Structural Geology 5 , 483-495.

Needham, D., Yielding, G., Freeman, B., 1996. Analysis of fault geometry and displacement patterns. Geological Society, London, Special Publications 99, 189-199. 
Nicol, A., Watterson, J., Walsh, J.J., Childs, C., 1996. The shapes, major axis orientations and displacement patterns of fault surfaces. Journal of Structural Geology 18, 235-248.

Nelson, M. 2006. 3D Geometry and Kinematics of Non-Colinear Fault Intersections. Unpublished PhD Thesis. Cardiff University

Nixon, C.W., Sanderson, D.J., Dee, S.J., Bull, J.M., Humphreys, R.J., Swanson, M.H., 2014. Fault interactions and reactivation within a normal fault network at Milne Point, Alaska. AAPG Bulletin. 98, 2081-2107.

Odinsen, T., Reemst, P., Van Der Beek, P., Faleide, J.I., Gabrielsen, R.H., 2000. Permo-Triassic and Jurassic extension in the northern North Sea: results from tectonostratigraphic forward modelling. Geological Society, London, Special Publications 167, 83-103.

Peacock, D.C.P., Sanderson, D.J., 1991. Displacements, segment linkage and relay ramps in normal fault zones. Journal of Structural Geology 13, 721-733.

Pochat, S., Castelltort, S., Choblet, G., Van Den Driessche, J., 2009. High-resolution record of tectonic and sedimentary processes in growth strata. Marine and Petroleum Geology 26, 1350-1364.

Rattey, R., Hayward, A., 1993. Sequence stratigraphy of a failed rift system: the Middle Jurassic to Early Cretaceous basin evolution of the Central and Northern North Sea, Geological Society, London, Petroleum Geology Conference series. Geological Society of London, pp. 215-249.

Reches, Z.e., 1987. Determination of the tectonic stress tensor from slip along faults that obey the Coulomb yield condition. Tectonics 6, 849-861.

Reeve, M.T., Bell, R.E., Duffy, O.B., Jackson, C.A-L., Sansom, E., 2015. The Growth of Non-Colinear Fault Systems; What Can We Learn From 3D Seismic Reflection Data? Journal of Structural Geology. 70, 141-155.

Roberts, A., Yielding, G., Kusznir, N., Walker, I., Dorn-Lopez, D., 1993. Mesozoic extension in the North Sea: constraints from flexural backstripping, forward modelling and fault populations, Geological Society, London, Petroleum Geology Conference series. Geological Society of London, 1123-1136.

Roberts, A., Yielding, G., Kusznir, N., Walker, I., Dorn-Lopez, D., 1995. Quantitative analysis of Triassic extension in the northern Viking Graben. Journal of the Geological Society 152, 15-26.

Sinclair, I., Withjack, M., 2008. Mid to Late Cretaceous structural and sedimentary architecture at the Terra Nova Oilfield, offshore Newfoundland-implications for the tectonic history of the North Atlantic. Central Atlantic Conjugate Margins, 125-141.

Smethurst, M., 2000. Land-offshore tectonic links in western Norway and the northern North Sea. Journal of the Geological Society 157, 769-781.

Stewart, I.J., Rattey, R.P. \& Vann, I.R. (1992) Structural style and the habit of hydrocarbons in the North Sea. In: Structural and Tectonic Modelling and its Application to Petroleum Geology (Ed. by R.M. Larsen, H. Brekke, B.T. Larsen \& E. Talleraas) NPF Spec. Publ.,1, 197-220

Stewart, S.A., 2001. Displacement distributions on extensional faults: Implications for fault stretch, linkage, and seal. AAPG Bulletin 85, 587-599.

Stewart, S.A., Clark, J.A., 1999. Impact of salt on the structure of the Central North Sea hydrocarbon fairways. Petroleum Geology Conference Series, Geological Society, London. 5, 179-200.

Ter Voorde, M., Faerseth, R., Gabrielsen, R., Cloetingh, S, 2000. Repeated lithosphere extension in the northern Viking Graben: a coupled or decoupled rheology? Special Publication-Geological Society of London 167, 59-82. 
Trudgill, B.D., 2002. Structural controls on drainage development in the Canyonlands grabens of southeast Utah. Underhill, J.R., Partington, M.A., 1993. Jurassic thermal doming and deflation in the North Sea: implications of the sequence stratigraphic evidence. Geological Society of London. 4, 337-345.

Vetti, V.V., Fossen, H., 2012. Origin of contrasting Devonian supradetachment basin types in the Scandinavian Caledonides. Geology 40, 571-574.

Walsh, J., Nicol, A., Childs, C., 2002. An alternative model for the growth of faults. Journal of Structural Geology 24, 1669-1675.

Walsh, J.J., Watterson, J., 1989. Displacement gradients on fault surfaces. Journal of Structural Geology 11, 307316.

Walsh, J.J., Watterson, J., 1991. Geometric and kinematic coherence and scale effects in normal fault systems. Geological Society, London, Special Publications 56, 193-203.

Watterson, J., 1986. Fault dimensions, displacements and growth. Pure and Applied Geophysics 124, 365-373.

Whipp, P., Jackson, C.L., Gawthorpe, R., Dreyer, T., Quinn, D., 2014. Fault array evolution above a reactivated rift fabric; a subsurface example from the northern Horda Platform fault array, Norwegian North Sea. Basin Research. $26,523-549$

Wilson, P., Elliott, G.M., Gawthorpe, R.L., Jackson, C.A.-L., Michelsen, L., Sharp, I.R., 2013. Geometry and segmentation of an evaporite-detached normal fault array: 3D seismic analysis of the southern Bremstein Fault Complex, offshore mid-Norway. Journal of Structural Geology. 51, 74-91.

Young, M.J., Gawthorpe, R.L., Hardy, S., 2001. Growth and linkage of a segmented normal fault zone; the Late Jurassic Murchison-Statfjord North Fault, northern North Sea. Journal of Structural Geology 23, 1933-1952.

Ziegler, P.A., 1975. Geologic evolution of North Sea and its tectonic framework. AAPG Bull 59, 1073-1097.

Ziegler, P.A., 1982. Triassic rifts and facies patterns in Western and Central Europe. International Journal of Earth Sciences 71, 747-772.

Ziegler, P.A., 1990. Tectonic and palaeogeographic development of the North Sea rift system. Tectonic Evolution of the North Sea Rifts. Clarendon Press, Oxford, 1-36.

Ziegler, P., 1992. North Sea rift system. Tectonophysics 208, 55-75. 


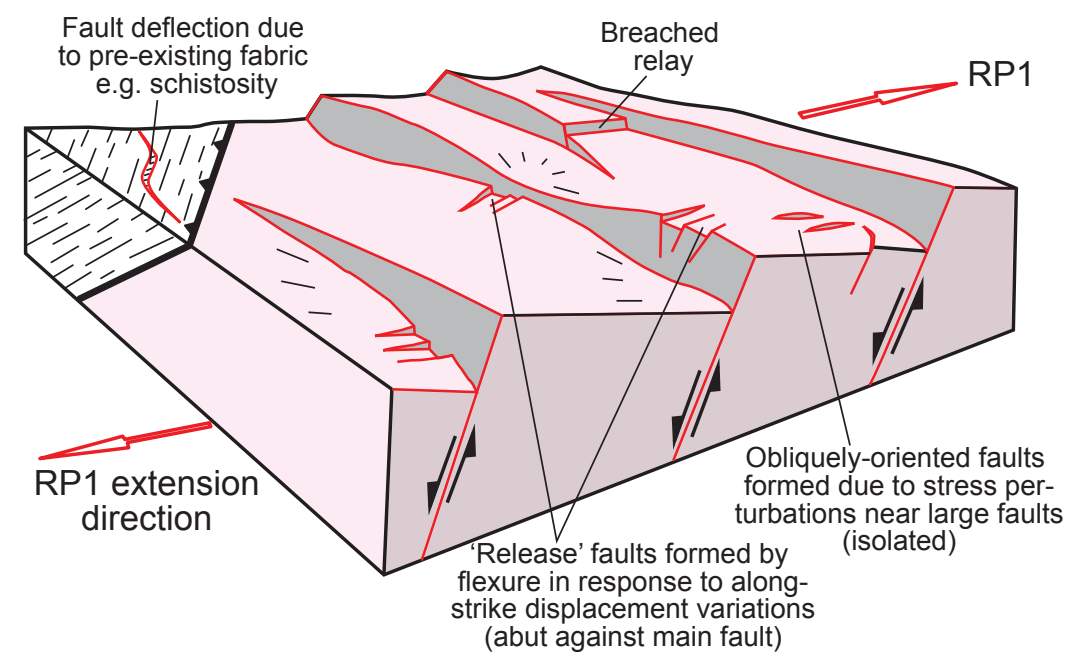

Figure 1 


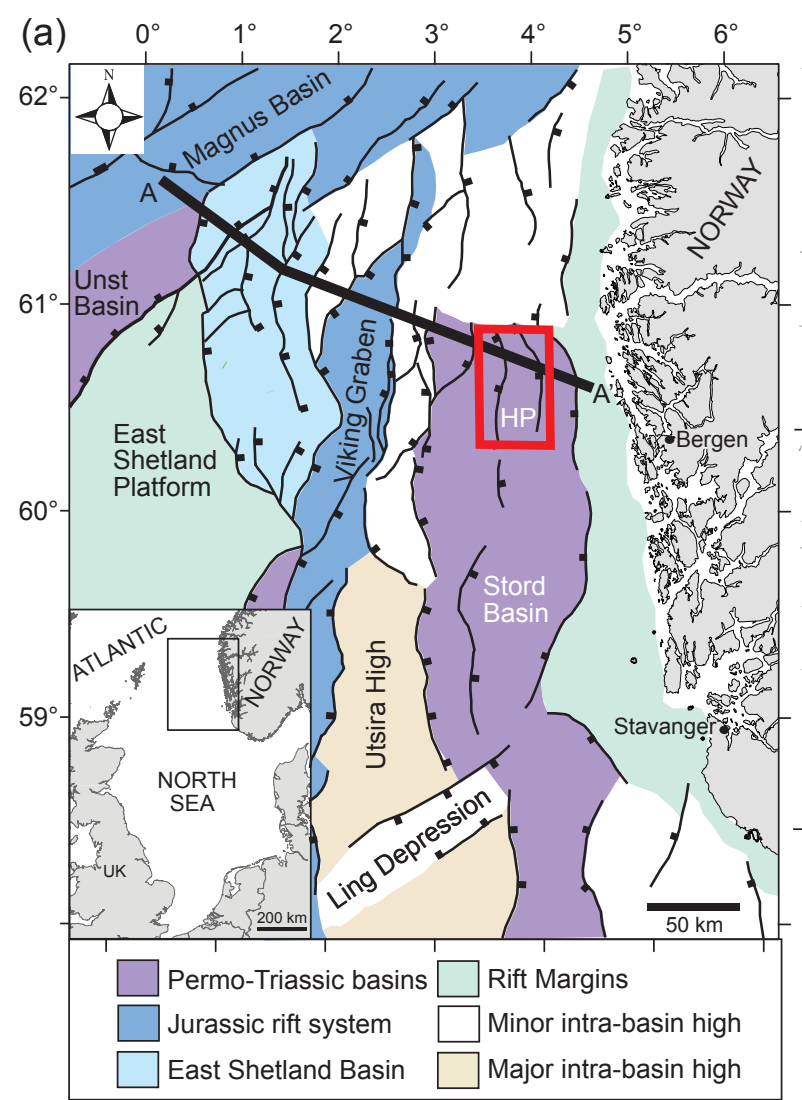

(b)
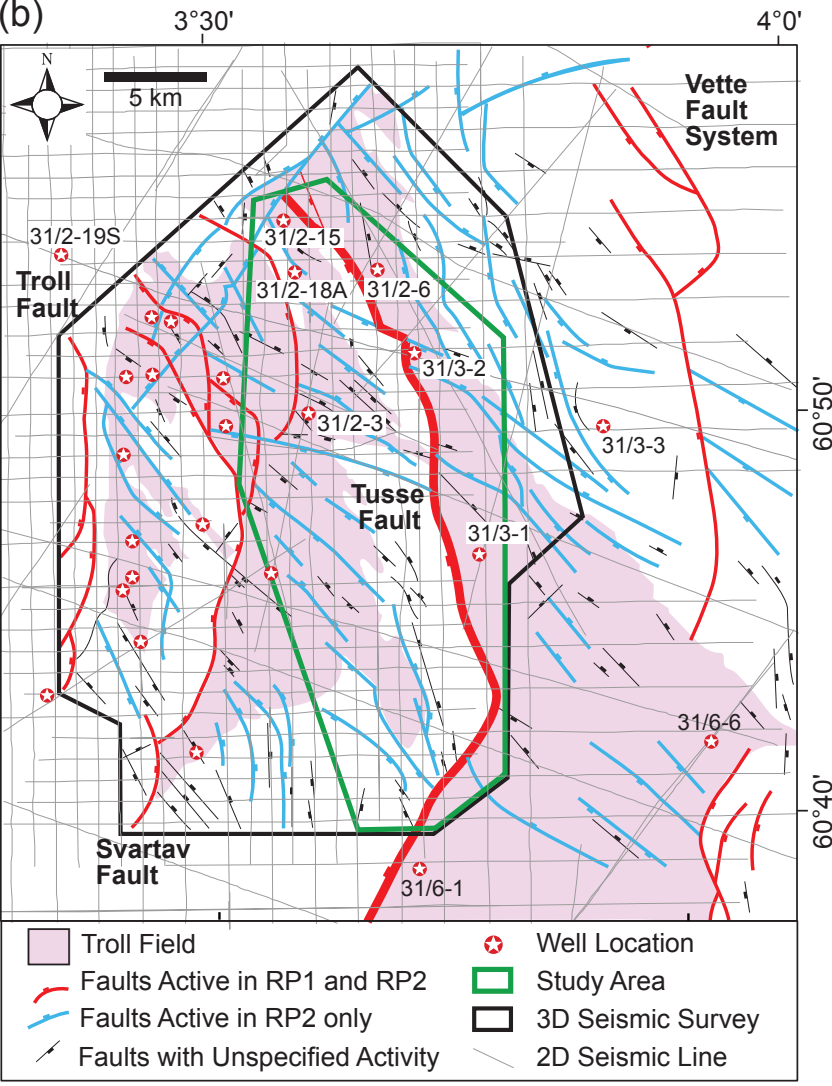

(c) $\mathrm{A}$

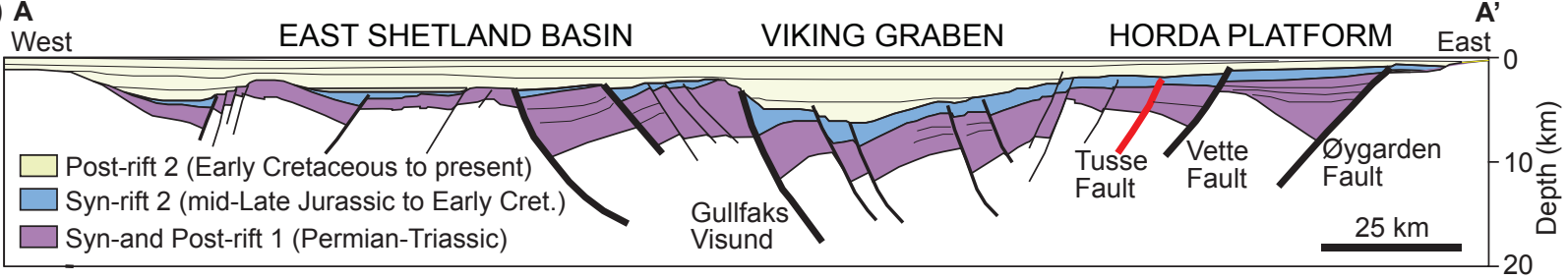

Figure 2 


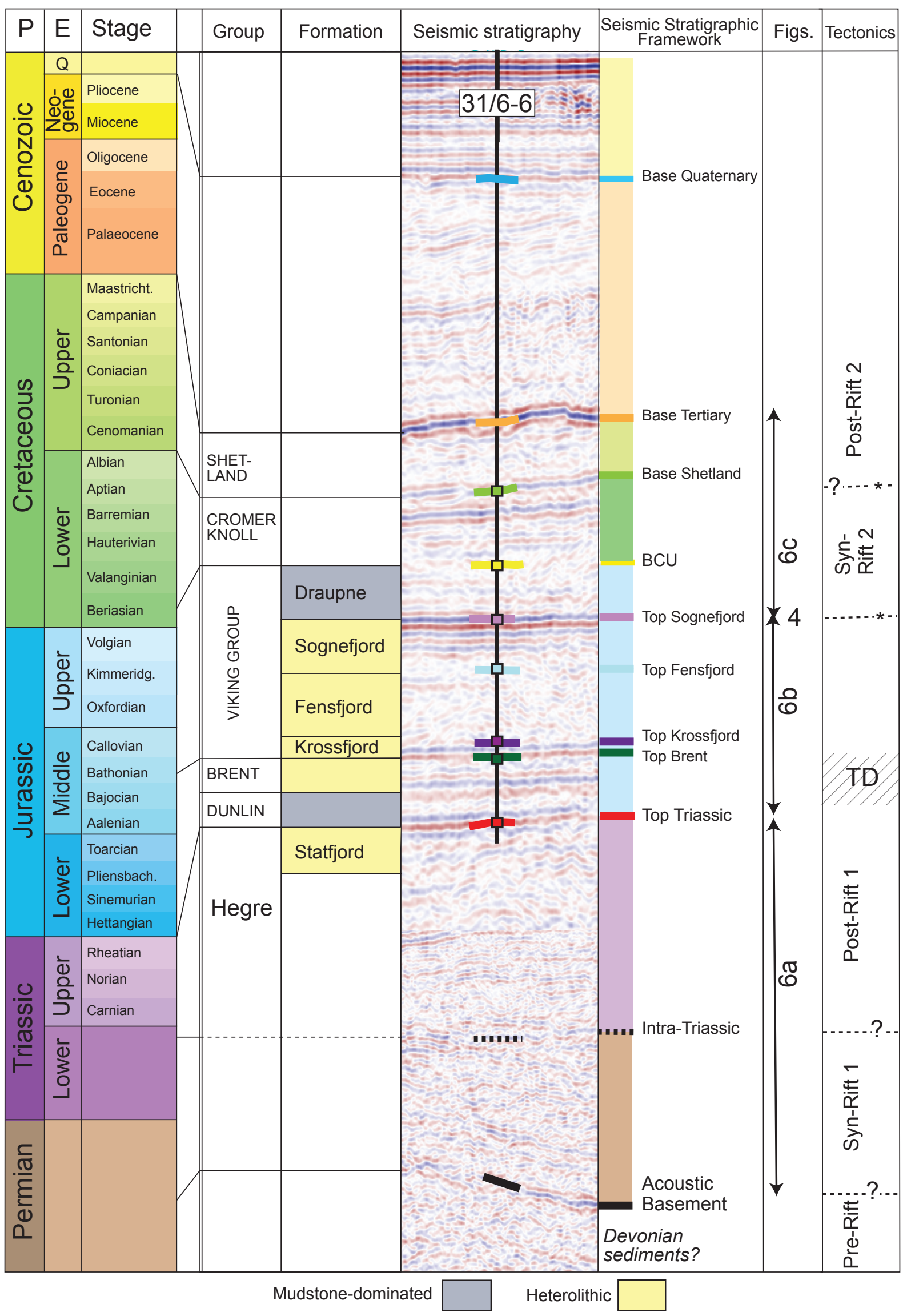

Figure 3 


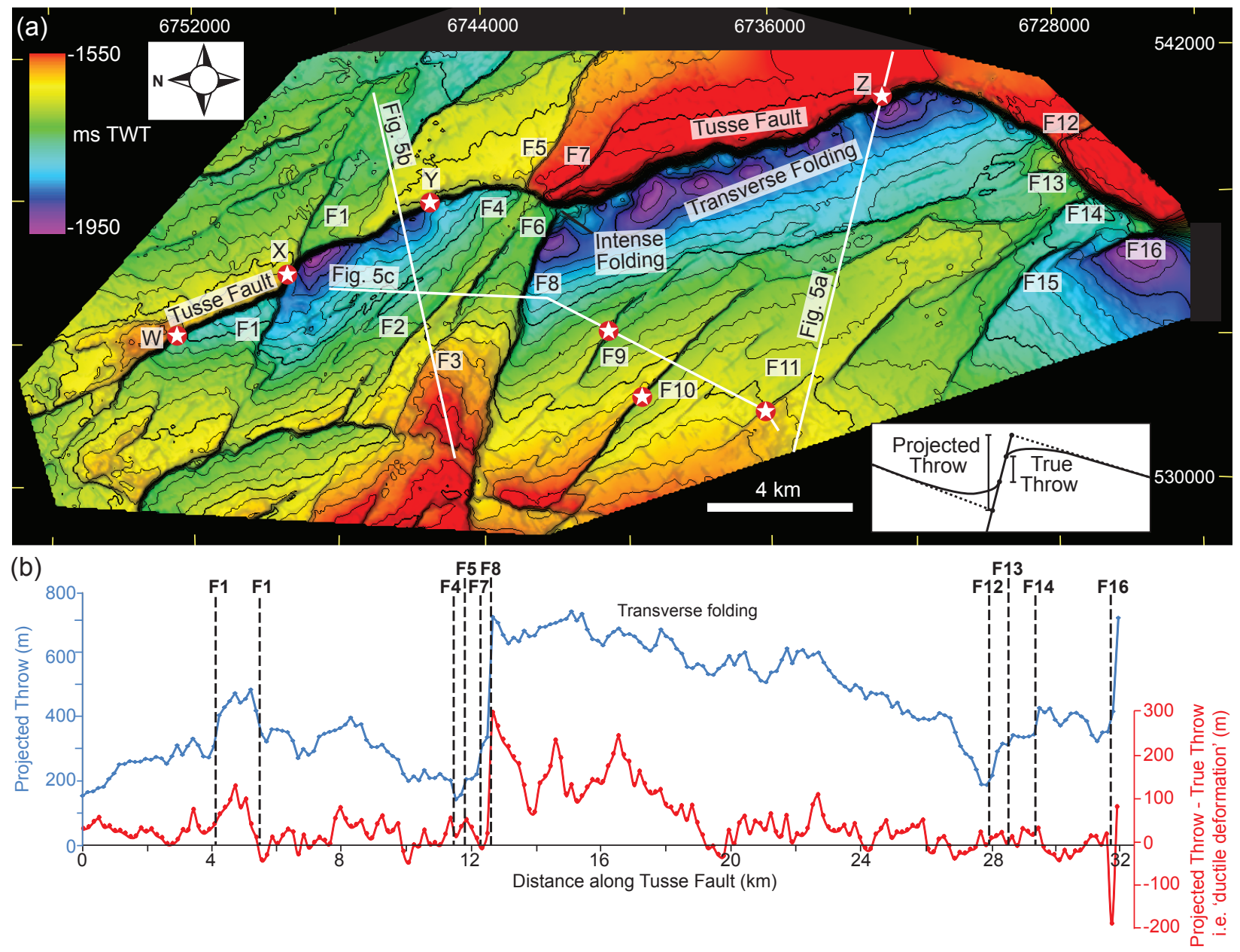

Figure 4 

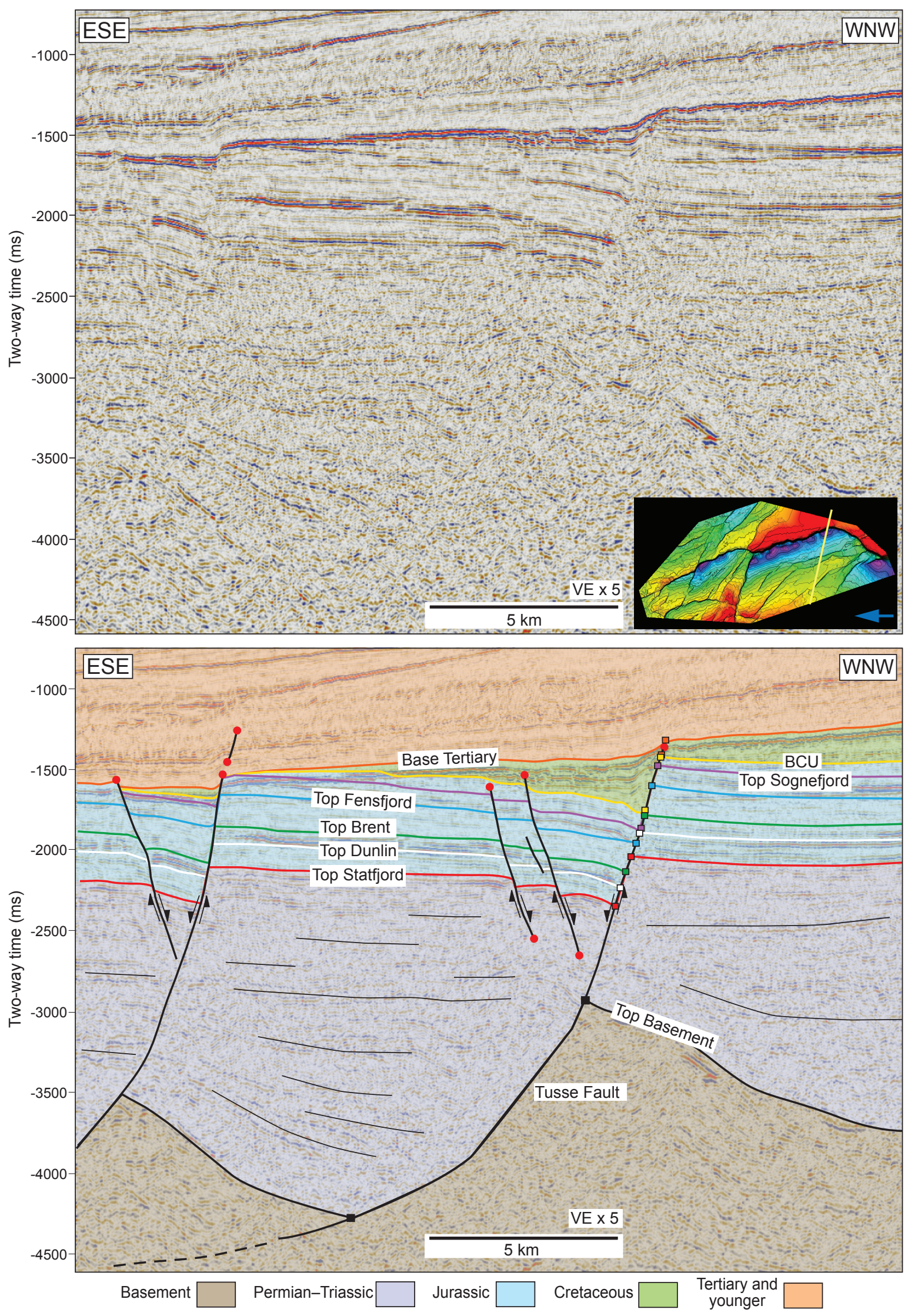

Figure 5a 

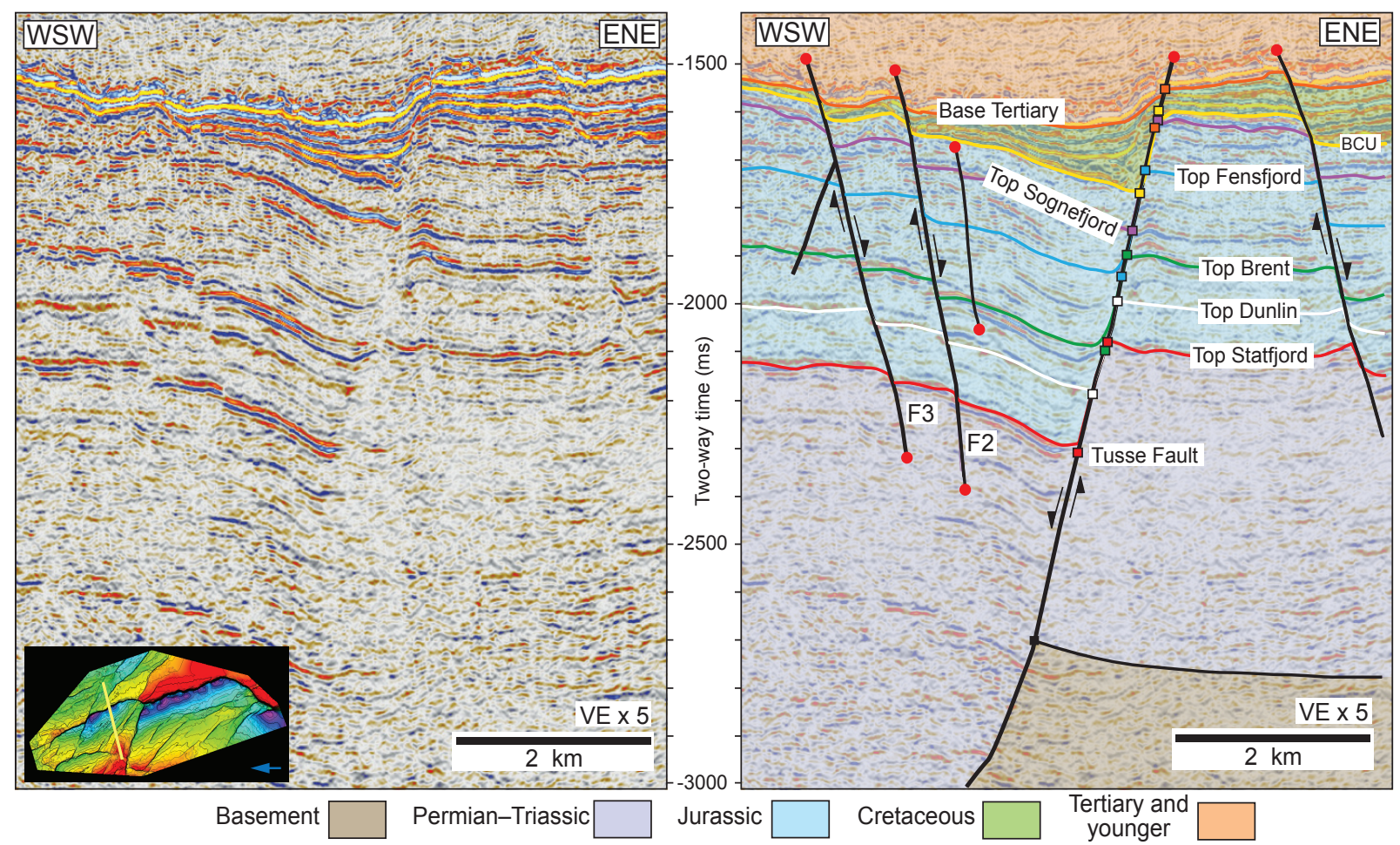

Figure 5b 

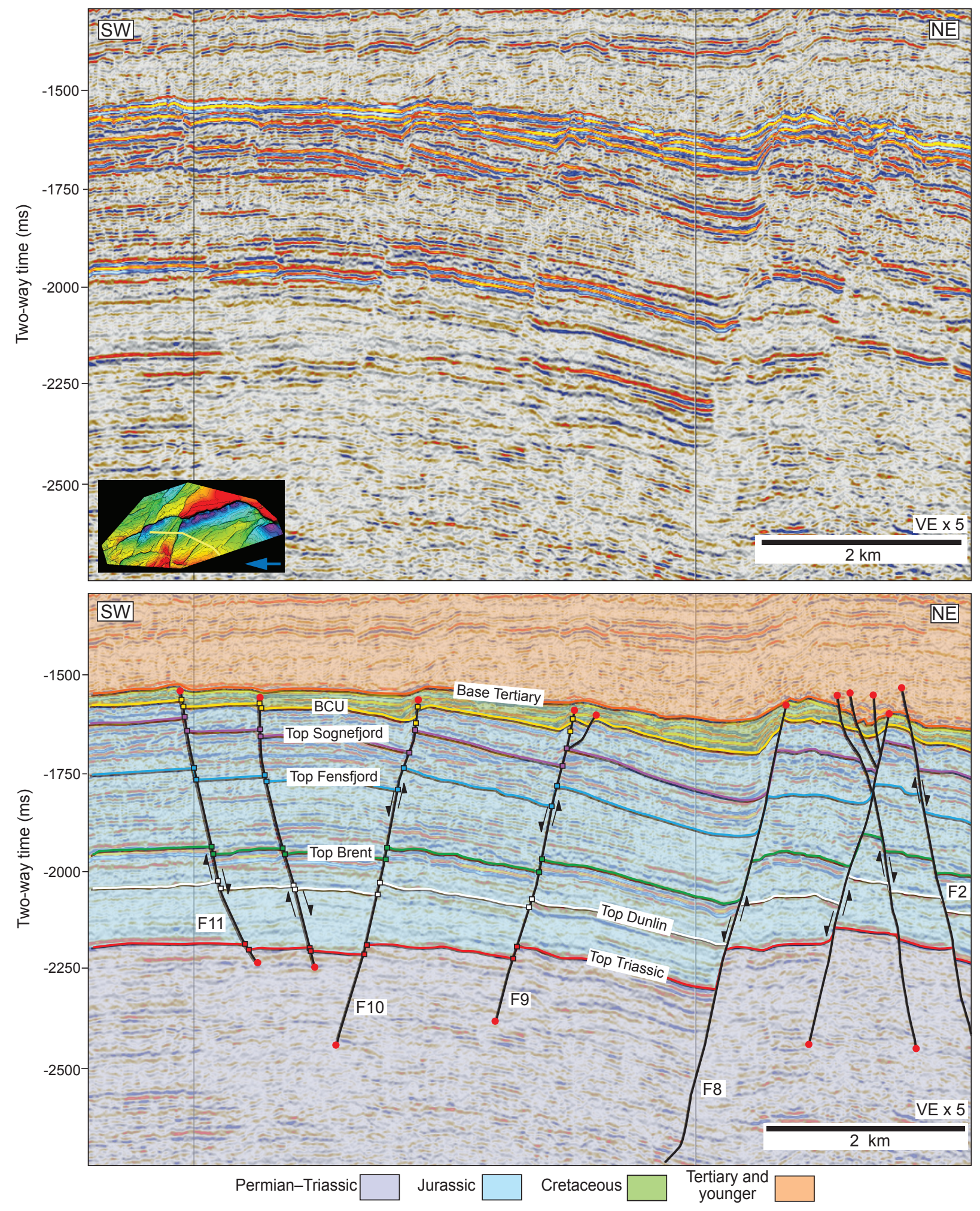

Figure $5 c$ 

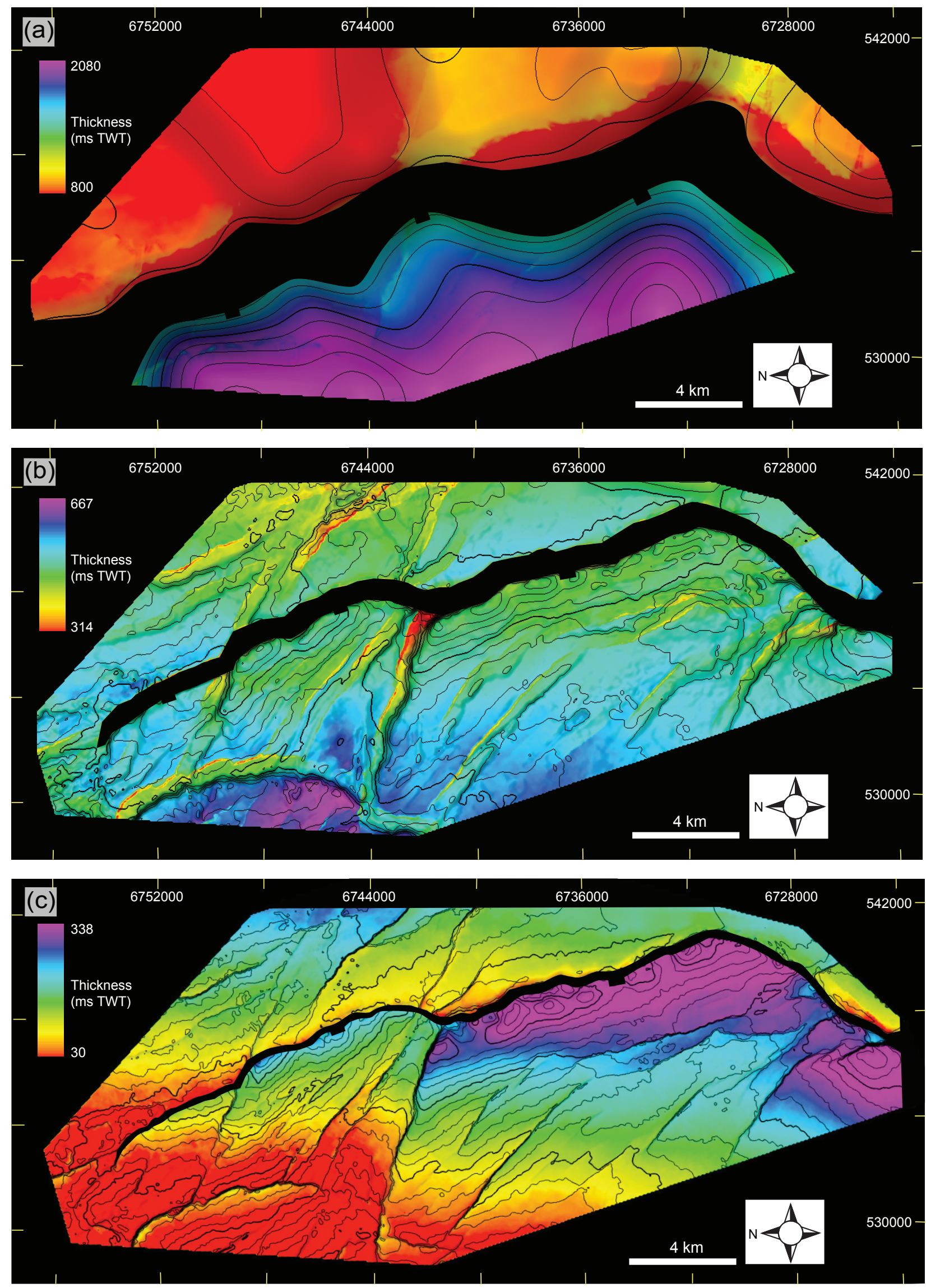

Figure 6 

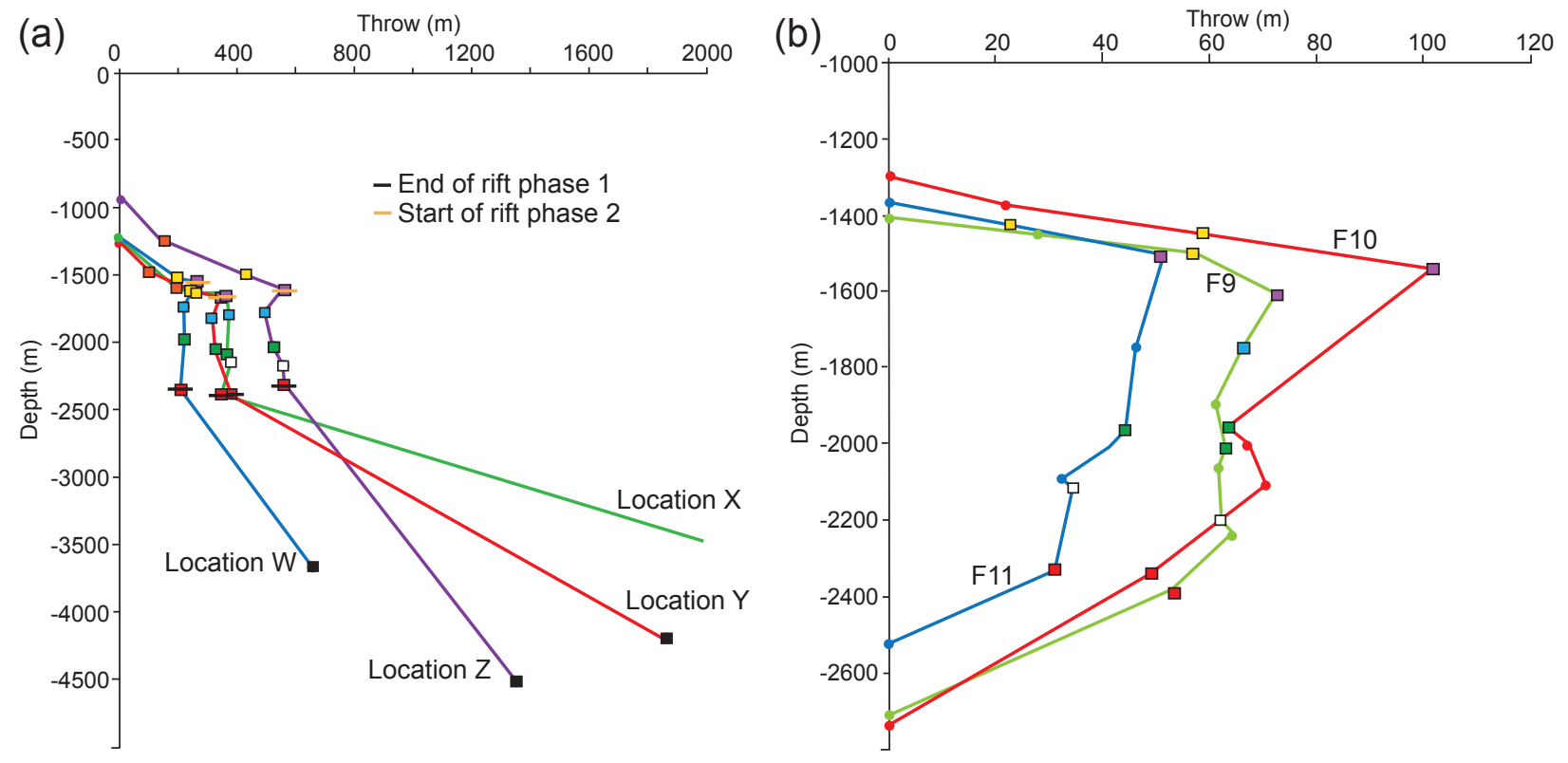

Figure 7 

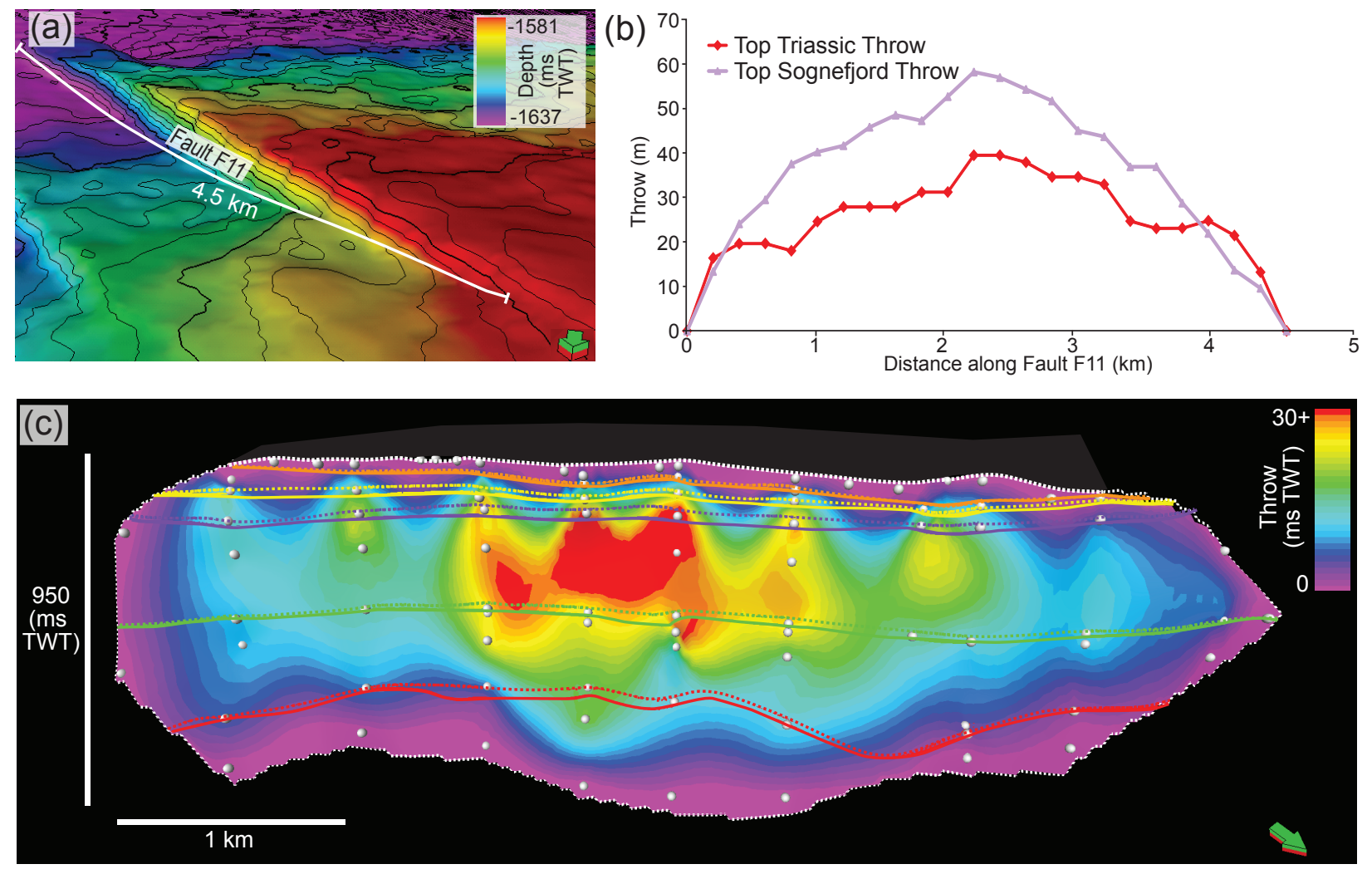

Figure 8 


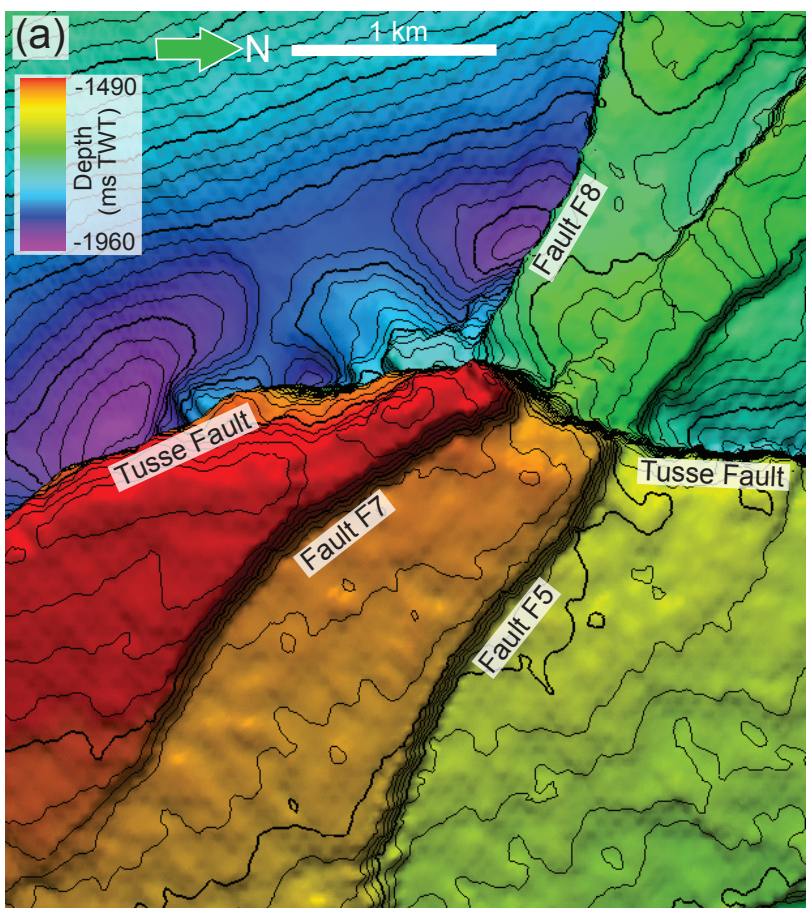

(c)

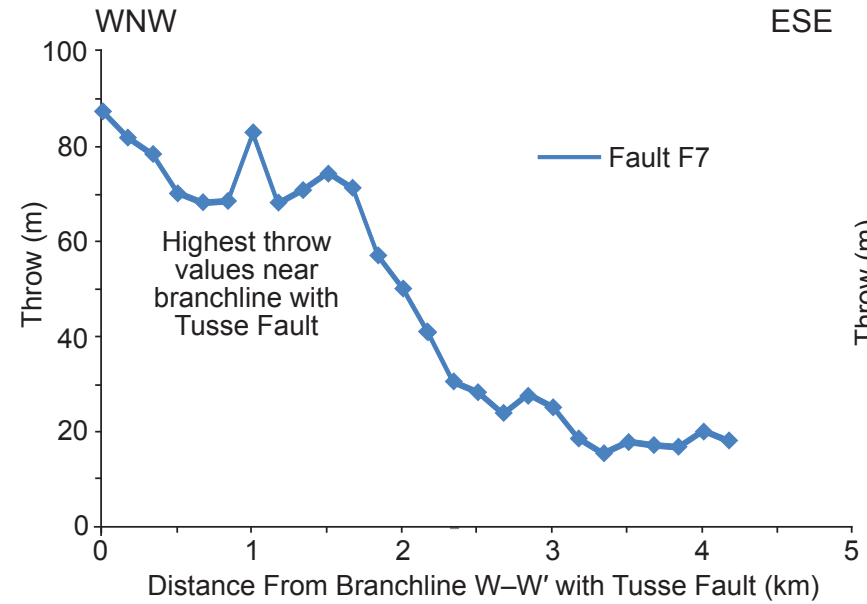

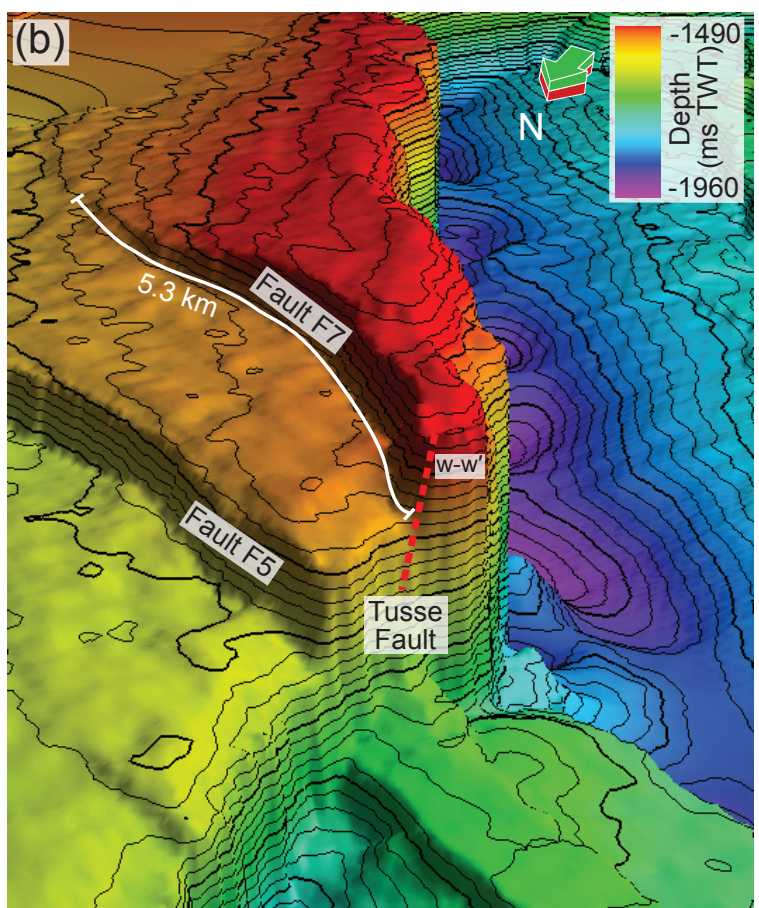

(d)

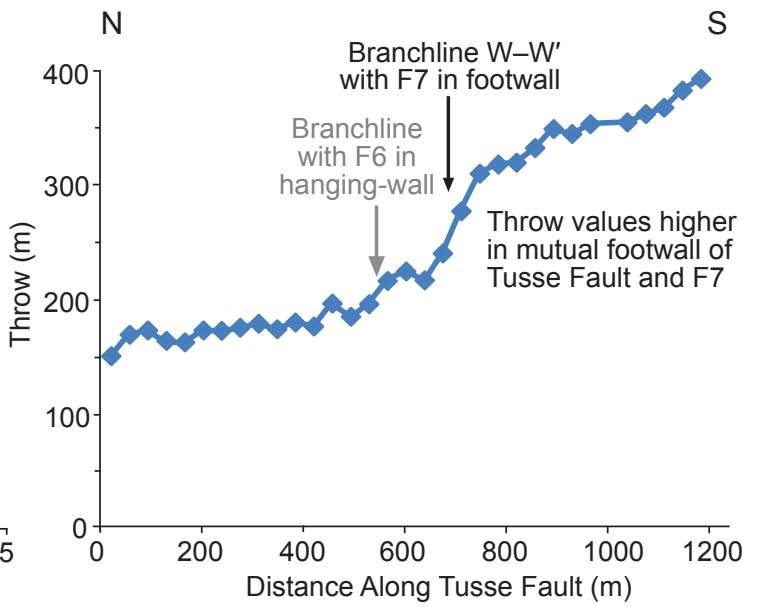

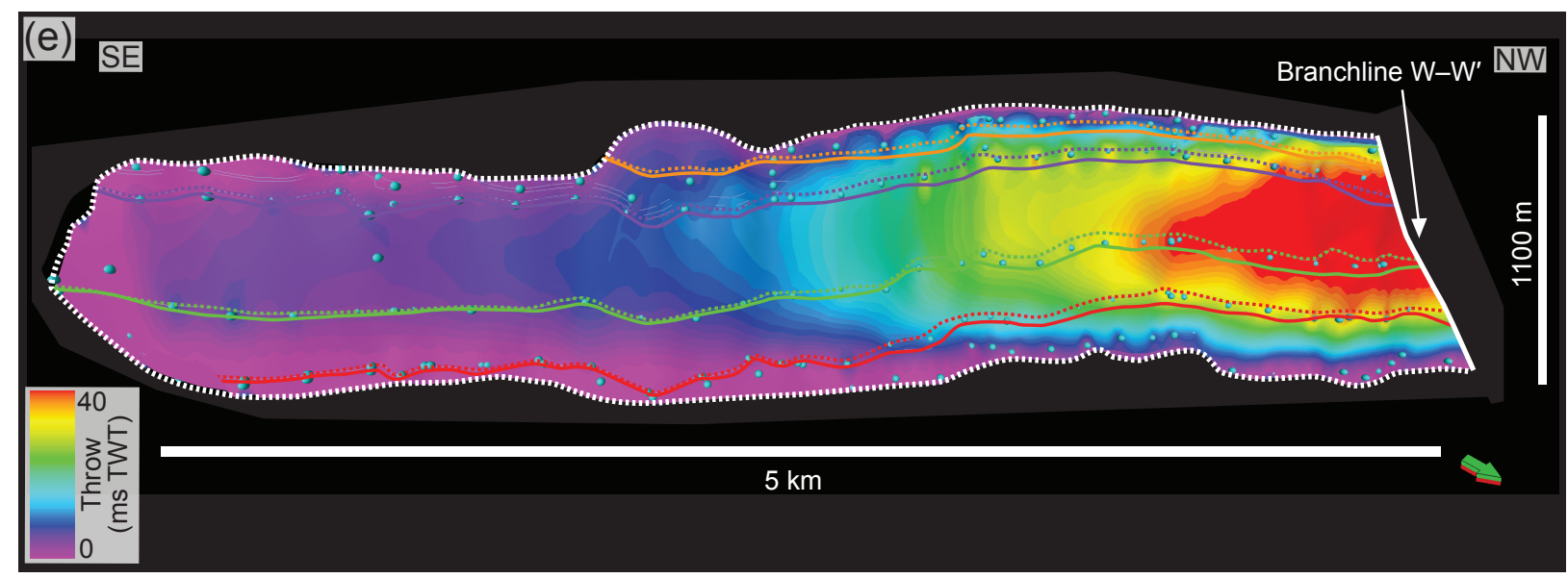

Figure 9 

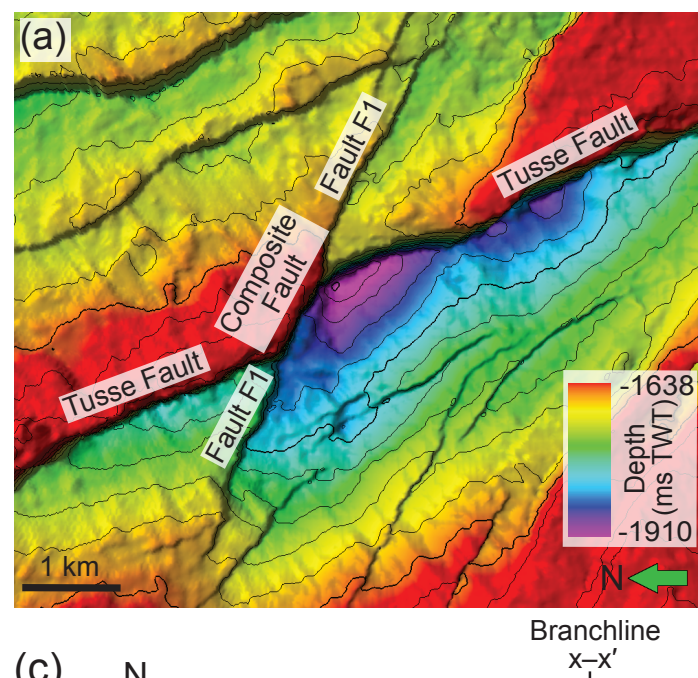

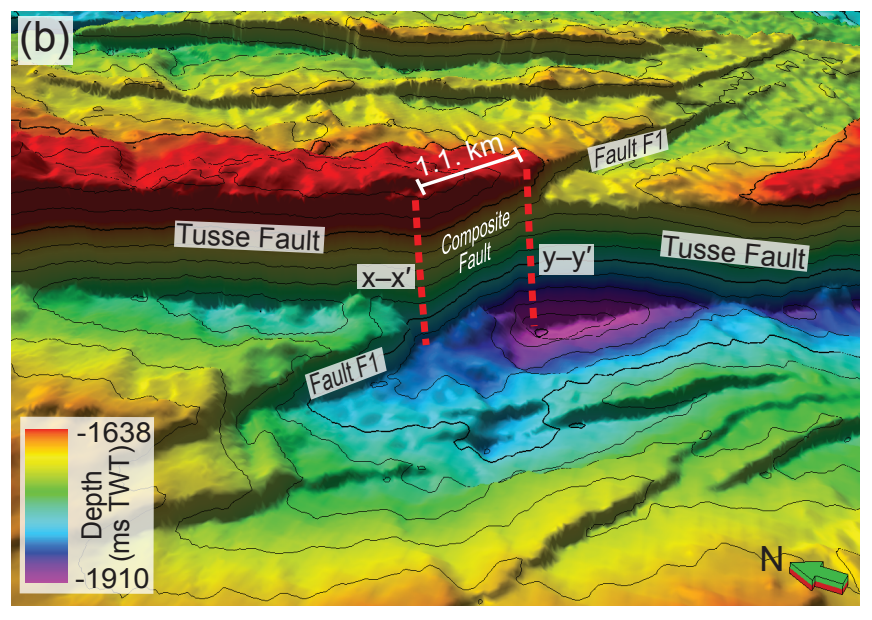

Branchline

S
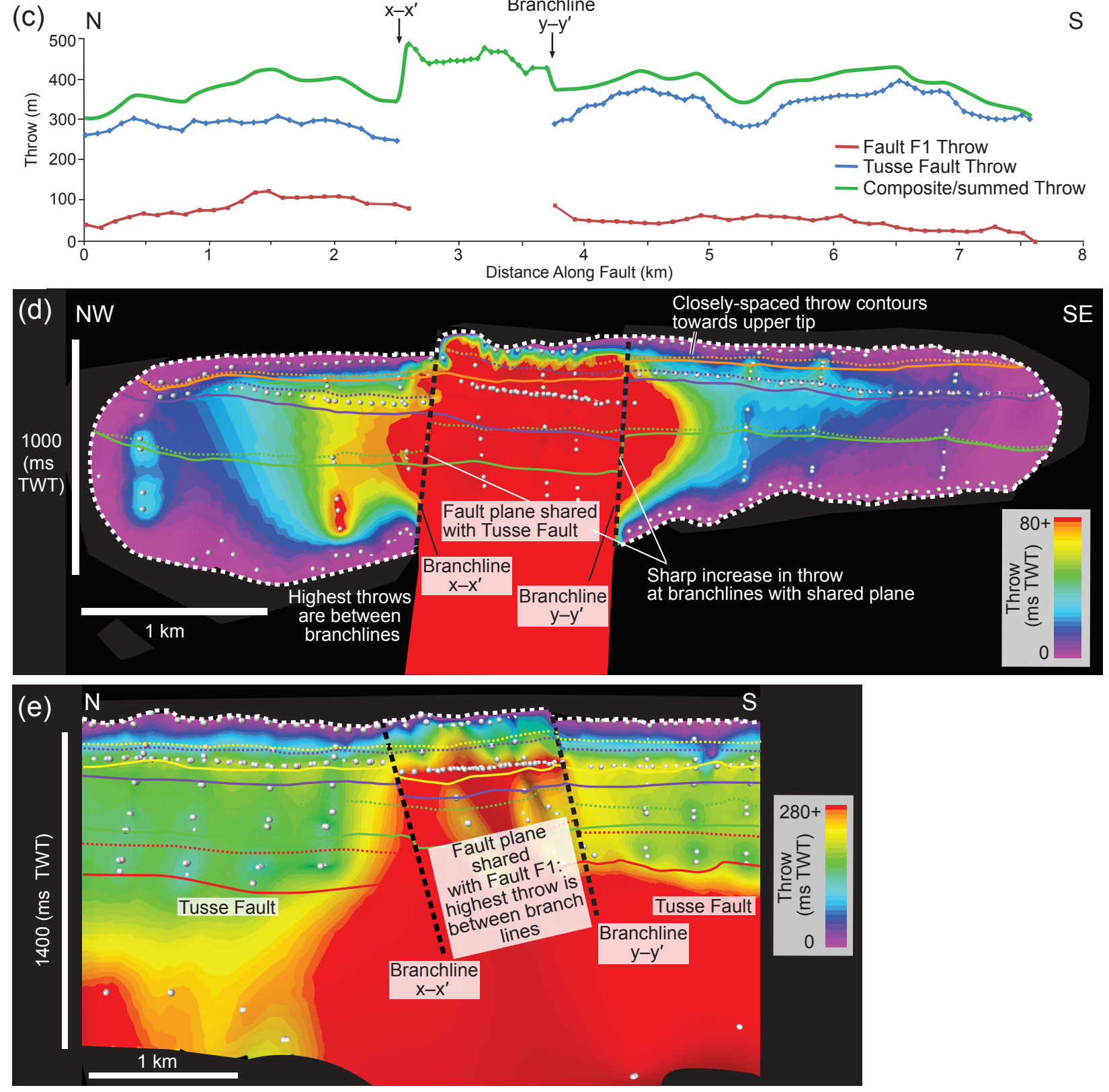

Figure 10 


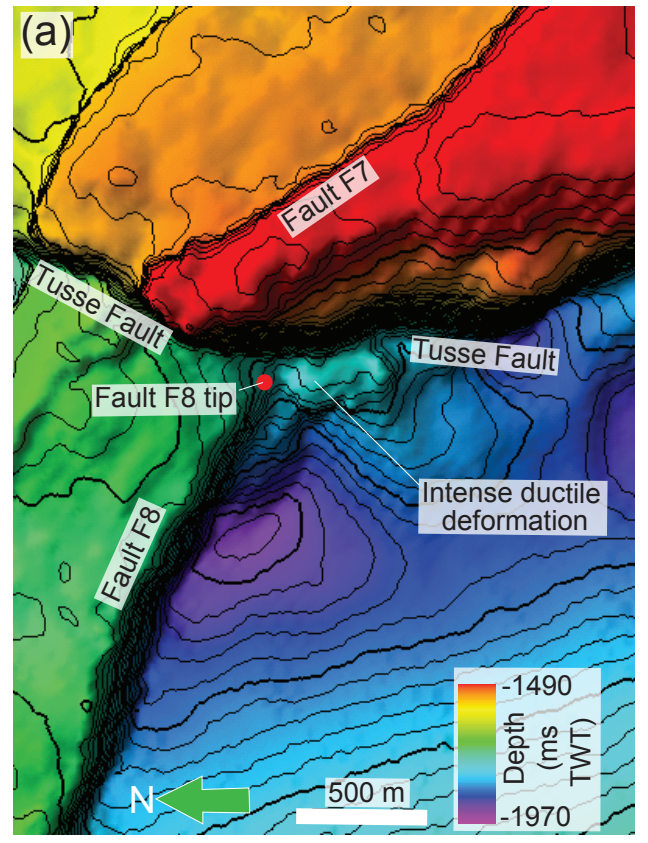

(c)

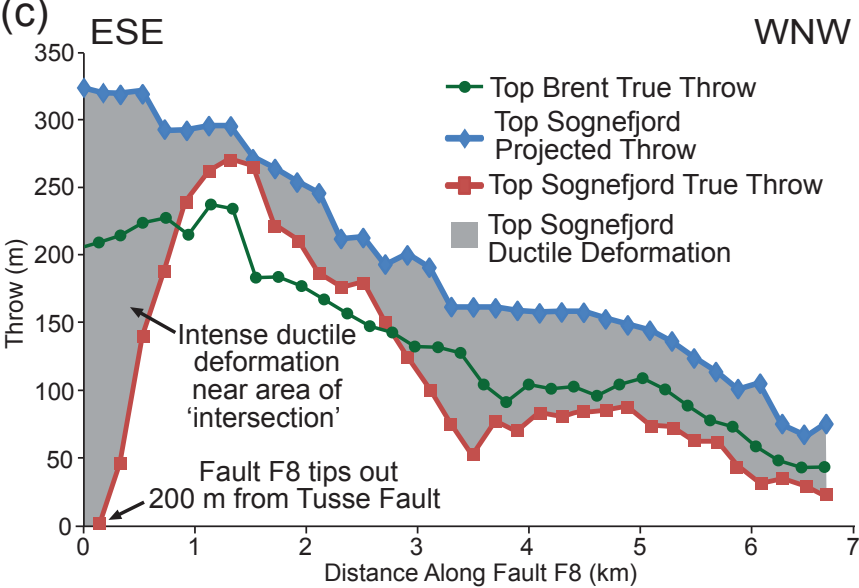

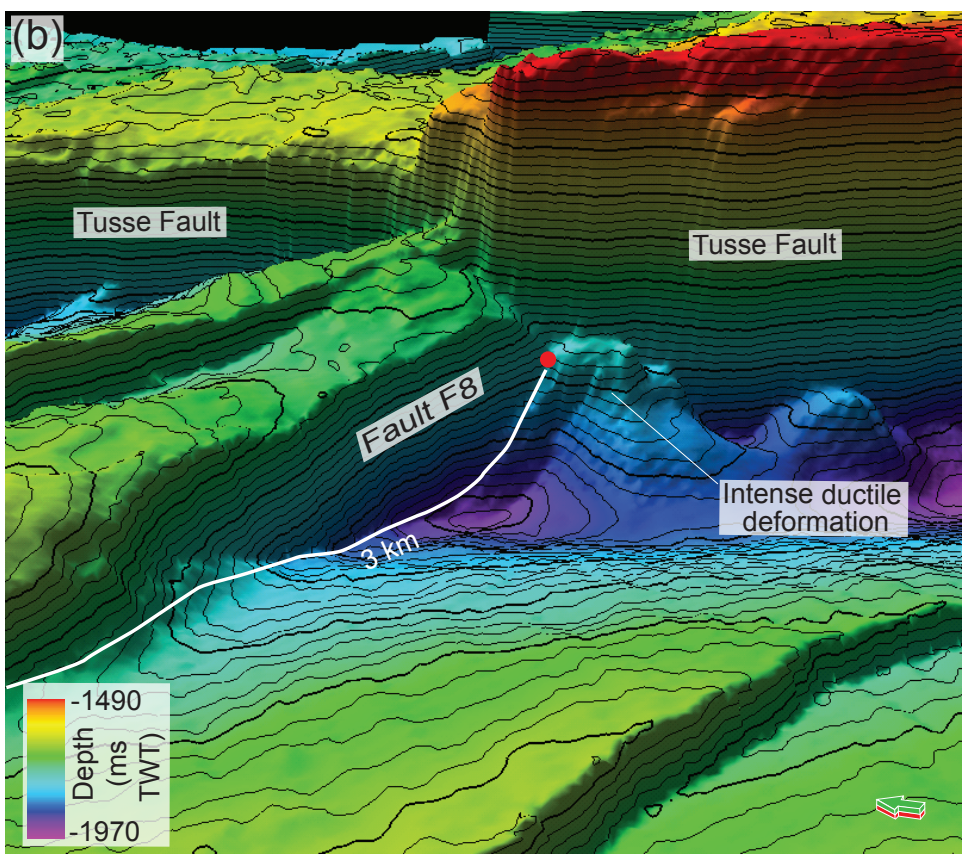

Step in throw at projected
branchline $z-z^{\prime}$ with

(d) $\mathrm{N} \quad \begin{gathered}\text { branchline } z \text { - } z^{\prime} \text { with } \\ \mathrm{F} 8 \text { in hanging-wall }\end{gathered}$

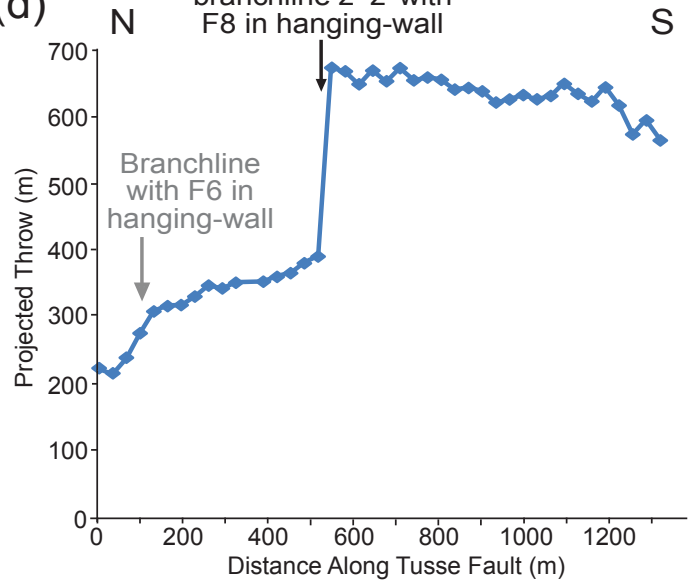

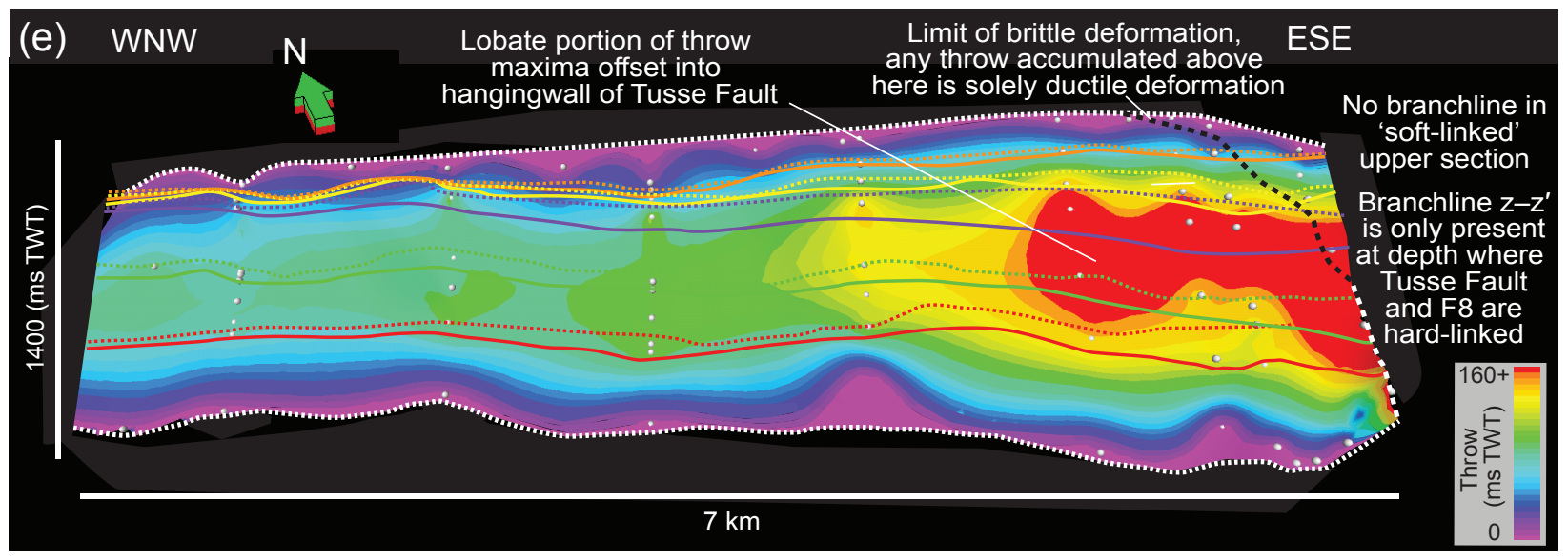

Figure 11 


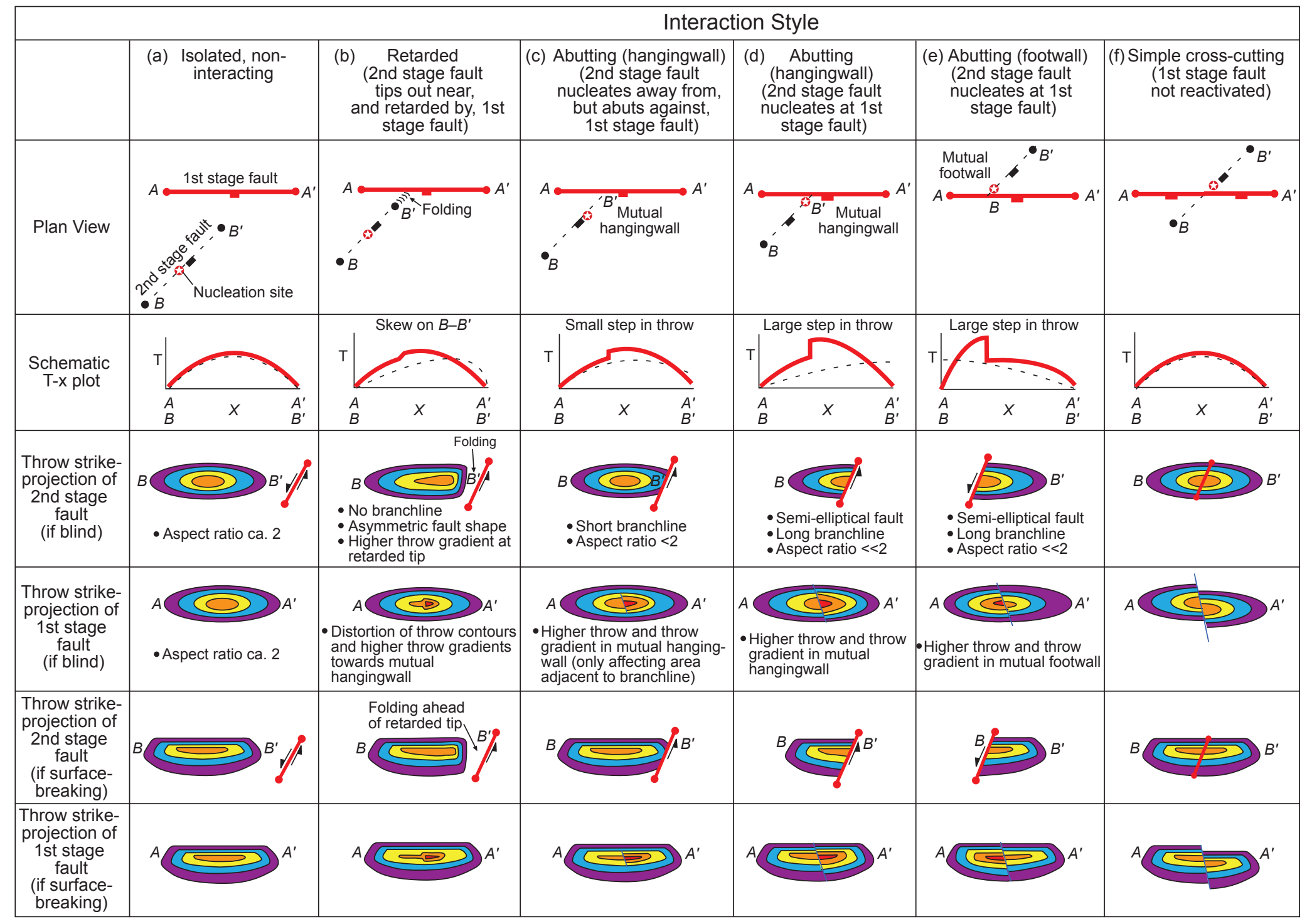

Figure 12 


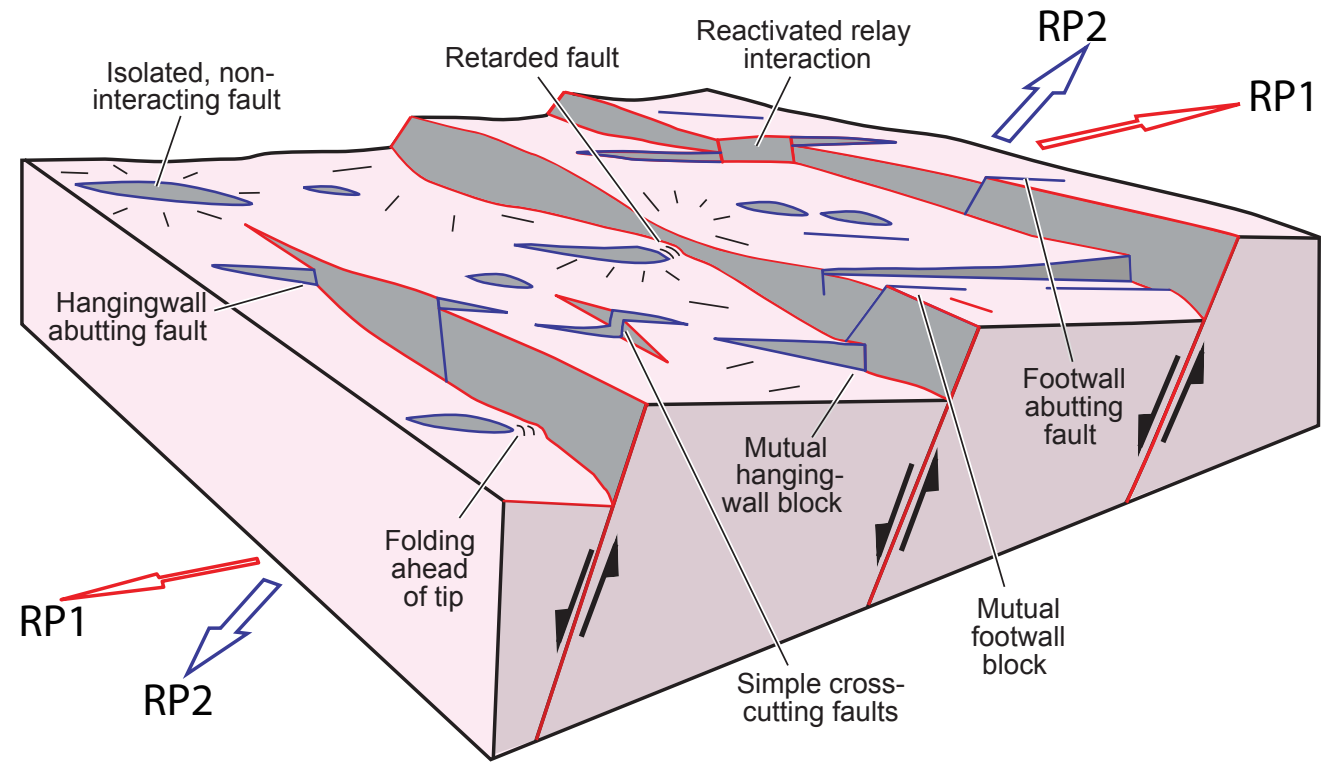

Figure 13 